Georgetown University Institutional Repository http://www.library.georgetown.edu/digitalgeorgetown

The author made this article openly available online. Please tell us how this access affects you. Your story matters.

Keesling, C. "Patrons of Athenian Votive Monuments of the Archaic and Classical Periods: Three Studies". Hesperia: The Journal of the American School of Classical Studies at Athens, Vol. 74, No. 3 (Jul. - Sep., 2005), pp. 395-426

Collection Permanent Link: http://hdl.handle.net/10822/555436

(C) 2005 The American School of Classical Studies at Athens

This material is made available online with the permission of the author, and in accordance with publisher policies. No further reproduction or distribution of this copy is permitted by electronic transmission or any other means. 
HESPERIA $74(2005)$

Pages $395-426$

\section{PATRONS OF \\ ATHENIAN VOTIVE \\ MONUMENTS OF \\ THE ARCHAIC AND \\ CLASSICAL PERIODS \\ Three STudies}

\begin{abstract}
In three studies of votive offerings, the author explores the role played by private patrons in the production of art and inscriptions in Athens in the Archaic and Classical periods. The studies concern additive sculptural groups produced by the contributions of multiple dedicators, a form of display explained within the context of votive religion; epigraphical evidence for collaboration between East Greek sculptors and Athenian patrons on 6th- and 5 th-century votive monuments; and dedications that have either been misidentified as belonging to Athenian potters and vase painters or erroneously reconstructed as metal or stone vases.
\end{abstract}

\title{
INTRODUCTION
}

The most pressing concern for most studies of artistic patronage in Athens in the Archaic and Classical periods has been public patronage, namely, identifying the patrons responsible for the construction of temples and other buildings and for the choice of subjects in architectural sculpture. ${ }^{1}$ After 480 B.C., the best-attested patron is the Athenian demos itself. In Archaic Athens, by contrast, the tyrant Peisistratos and his sons and the post-Kleisthenic democracy have been identified by modern scholars as patrons or sponsors of public art. ${ }^{2}$ Even the study of Athenian blackand red-figure pottery, an obvious realm for the exploration of the role of

Agora Excavations. Aileen Ajootian, Nancy Bookidis, Ben Millis, Peter Nulton, Olga Palagia, and two anonymous Hesperia readers contributed references that improved this paper. Finally, extra thanks go to Karen E. Rasmussen for producing Fig. 8 and to Robert Houston for scanning my drawings.

2. Peisistratid tyranny: see Shapiro
1989, 1995; also Angiolillo 1997 and the essays in Sancisi-Weerdenburg 2000 for up-to-date bibliography. Kleisthenic democracy: see esp. Coulson et al. 1994, Boedeker and Raaflaub 1998, and Morris and Raaflaub 1998, collections of essays inspired by the 2,500th anniversary in 1992-1993 of Kleisthenes' reforms. graphical Museum; and director John Camp and Jan Jordan of the Athenian poulou of the Acropolis Museum; director Charalambos Kritzas and Chara Karapa-Molisani of the Epi- 
private patrons, has been approached in light of Peisistratid iconography and cult sponsorship since the publication of John Boardman's first article on Peisistratos and Herakles in $1972 .{ }^{3}$ In the private realm, Archaic Attic funerary monuments have attracted the lion's share of attention. A considerable number of studies concerning the significance of their sculpture and inscriptions followed the publication of G. M. A. Richter's sculptural catalogue (1961) and L. H. Jeffery's 1962 epigraphical catalogue of inscribed funerary monuments from Athens and the Attic countryside. ${ }^{4}$ One major issue regarding patronage raised by private funerary monuments in Athens - the apparent gap between the Archaic monument series and the resumption of inscribed funerary stelai commemorating private individuals late in the third quarter of the 5 th century B.c. - has been explained as the outcome of various larger factors at work in the public sphere. ${ }^{5}$

Votive monuments dedicated in sanctuaries in Athens and Attica have been less intensively studied as products of patronage than architecture, vase painting, and funerary sculpture. ${ }^{6}$ Though the Athenian demos emerges as a patron of votive statues in the Late Archaic period, the majority of inscribed, monumental sanctuary dedications of the Archaic and Classical periods attest to the patronage of private individuals. ${ }^{7}$ The bulk of the evidence for dedications of freestanding sculpture in sanctuaries is concentrated on the Athenian Acropolis. The Acropolis material, in particular the preserved votive inscriptions, permits the study of patronage by individual, named patrons. The rich prosopographical evidence for the

3. Boardman 1972. For subsequent bibliography, see Shapiro 1989, pp. 1517, 61-64, 157-163; Angiolillo 1997, pp. 134-142; Blok 2000, pp. 28-30.

4. On Archaic funerary monuments, see Richter 1961; Jeffery 1962; and esp. D’Onofrio 1982, 1988; SourvinouInwood 1995; Kaltsas 2002, on the Phrasikleia kore and kouros from Merenda in Attica; and Niemeier 2002, the preliminary publication of new sculptures found in the Kerameikos.

5. The head of a kouros found in the Kerameikos and dated stylistically to ca. 480 в.c. is now interpreted as the latest monument in the Archaic series (Knigge 1969; 1991, pp. 33-34, fig. 32). Explanations for the gap in funerary monuments in Athens include a sumptuary law dated after Solon's reforms (Garland 1989; Seaford 1994, pp. 7492; Parker 1996, pp. 133-135; Engels 1998, pp. 97-106); the dismantling of Archaic tombs for reuse in the Themistoklean city wall in 478 в.c. (S. Morris 1992, pp. 305-307); a 5th-century culture of restraint in public display (Morris 1994); the displacement of commemorative monuments from the private sphere to the public realm of inscribed casualty lists and collective commemoration of the war dead in the Demosion Sema (Stupperich 1994); the Athenian plague of 429 в.C. (Mikalson 1984, pp. 223-224); and the Periklean citizenship law of $451 / 0$ B.c. (Meyer 1993, pp. 112-119; Stears 2000 , p. 52, who also dates the earliest Classical stelai to the 430 s or 440 s B.c. rather than after ca. 430 в.с.). Whiteground lekythoi used as grave goods in the period between ca. 480 and ca. 430 continued to represent monumental grave markers (I. Morris 1992, pp. 104-118); Clairmont (1983, pp. 6073) argued that these represented public monuments in the Demosion Sema. Role of the Parthenon sculptors: Friis Johansen 1951; Richter 1961, pp. 54-55; cf. Engels 1998, pp. 113119.

6. Exceptions: Schneider 1975 and Holloway 1992 on the Acropolis korai, but now cf. Keesling 2003, pp. 85-88. Most studies of votive offerings focus on portable, nonmonumental votives; see, e.g., the conference papers published in ScAnt 3-4 (1989-1990). One major exception is Jacquemin 1999 on monumental votive offerings at Delphi. For Archaic and Classical votive statues on the Acropolis, see Keesling 2003, and also Hurwit 1999, pp. 57-63, 116136 passim, 145-153, 199, 250-253; Kissas 2000; Shapiro 2001.

7. The only certain example of a dedication of freestanding sculpture by the Athenian state in the Archaic period is the quadriga group commemorating the victory over the Boiotians and Chalkidians in 506 в.c. (replaced after the Persian sack of the Acropolis in 480); the preserved inscriptions are $D A A 168$ and 173 ( $\left.I G \mathrm{I}^{3} 501\right)$. A colossal votive column without a preserved inscription, published by Korres (1997), was destroyed in 480 but cannot be dated precisely, and thus it could be attributed either to the Peisistratids or to the Athenian demos. If the monument was replaced after 480, as Korres suggests, it is more likely to have been a public monument of the democracy, by analogy with the quadriga group noted above and the Tyrannicides in the Agora. 
dedicators of votives in Athens intersects in interesting ways with data from other sources, among them funerary monuments, Attic black- and red-figure pottery, and ostraka. In addition, the inscribed dedications of the Archaic period in Athens were less conventional than the funerary monuments of the same period, presenting greater variations in size, medium, and sculptural types that may express more directly the patron's contribution to the monument's form. Unlike funerary monuments, private dedications in Athens also bridge the gap between the Archaic and Classical periods without any apparent break. ${ }^{8}$

In this article I present three separate studies concerned with private patrons and their dedications in Athenian sanctuaries. The first study deals exclusively with Archaic material, but the phenomena treated in the second and third studies extend into the Classical period. Joint dedicationsvotive monuments inscribed with the names of multiple dedicators-have recently been studied by Christoph Löhr under the larger rubric of "Familienweihungen." Three well-preserved examples of one particular class of joint dedications are examined here in the first study: these are inscribed bases for votive statues or statuettes featuring later additions to the original monument, as indicated by separate inscriptions and multiple phases of cuttings for the attachment of sculpture. These additions resulted in the dedication of multiple statues or statuettes grouped together on the same base, but clearly not conceived as thematically unified sculptural "groups."

In the second study, I reevaluate the significance of letter forms and spelling as evidence for the ethnic origins of the sculptors, letter cutters, and patrons of votive monuments in Athens and Attica. Though the inscriptions on funerary monuments have been used to link closely sculptors from Ionia and the Cyclades with East Greek clienteles living in Athens, the evidence of inscribed dedications from the same period seems to attest collaboration between East Greek craftsmen and Athenian patrons.

The third study deals with a group of inscribed stone bases from the Acropolis identified by A. E. Raubitschek as supports not for statues, but instead for stone or bronze vessels dedicated by Athenian potters and vase painters. I will show that only one of these bases is likely to have supported a bronze vase, and that this should be interpreted as agonistic or sacrificial in significance rather than as the dedication of a potter or vase painter. In addition, a fragmentary 4th-century dedication attributed to the Athenian potter Kittos may in fact be an anatomical votive from the Athenian Asklepieion on the South Slope of the Acropolis.

\section{JOINT DEDICATIONS}

8. For the chronology of the Acropolis dedications, see Keesling 2003, pp. 60-61.

9. Löhr 2000.

10. Altars: Lazzarini 1976, nos. 762, 764,766 ; ceramic vase: no. 314 ; metal vessel: no. 689 .
One subset among the sanctuary dedications of the Archaic and Classical periods recently collected by Löhr consists of private joint dedications made together by more than one named member of the same family. As many as 60 of these from sanctuaries throughout the Greek world were included by M. L. Lazzarini in her catalogue of Archaic votive inscriptions, consisting not only of freestanding statues, but also of votive altars, ceramic vases, and metal vessels. ${ }^{10}$ Löhr discusses 74 preserved examples dedicated jointly 
by relatives, dating from the Archaic period through the end of the 4th century в.c. ${ }^{11}$ The Athenian Acropolis has produced by far the largest concentration of joint dedications in the Greek world, with at least 33 examples dating between ca. 600 and ca. 450 B.c. and accounting for nearly a tenth of 6 th- and 5 th-century dedications inscribed on stone from the sanctuary. ${ }^{12}$

Some general observations about the joint dedications from the Acropolis are in order. Surprisingly few of the inscriptions specify the relationship between the dedicators. Nine were dedicated jointly by relatives, and two by fellow demesmen; the remaining 22 were dedicated by individuals whose relationship to one another remains uncertain. Though many of these probably were relatives, it seems unsafe to assume a priori that all were connected by family ties. ${ }^{13}$ The familial relationships directly attested by the formulas of the dedicatory inscriptions all fall within the definition of the anchisteia, the bilateral kin group extending to the degree of second cousins. ${ }^{14}$ The Acropolis material does not appear to include any joint dedications by men and women, and the only examples of such in Lazzarini's catalogue are a mid-5th-century dedication from Locri (no. 342), an altar from Eretria dedicated jointly by a father and daughter (no. 262), and the Late Archaic dedication of the husband and wife Demokydes and Telestodike from Paros (no. 803) made from their common property

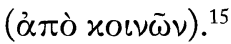

The simplest explanation for the lack of joint dedications by men and women before the 4th century may be that husbands and wives normally did not hold property in common, and that (in Athens at least) daughters received their inheritance in the form of a dowry separately from their brothers. ${ }^{16}$ One indication that inheritance might have been an important occasion for joint dedications is the frequent use in their inscriptions of the term aparche, "first-fruits"; though inheritance was not the only occasion for dedicating an aparche, this is the term used by Herodotos (1.92.14 ) in the later 5 th century to describe Croesus's dedications in various Greek sanctuaries from the proceeds of his inheritance. ${ }^{17}$

11. Löhr's (2000, passim) examples of joint dedications appear under the classification "von mehreren Verwandten errichtet."

12. Joint dedications from the Acropolis dating to the 6th and 5th centuries: $D A A 8,29,30,41,53,80$, 90, 93, 94, 99, 110, 112, 114, 115, 117, $131 \mathrm{a}\left(I G \mathrm{I}^{3} 843\right), 160,178,186,209$, 210, 217, 221, 227, 228, 291, 292, 297, $317,331,339,382,384$. My list differs from that of Raubitschek $(D A A$, p. 466), in some cases (DAA 131a, 191) because I favored alternative restorations or interpretations, and in others (e.g., $D A A 75,83,162,279)$ because I adopted a more conservative approach to restoration.

13. Joint dedications by relatives:
$D A A$ 29, 110, 112, 384 (two brothers); 297 (two sisters); 53, 217, 228, 291 (father and children or siblings). Demesmen: $D A A 94,160$; for the financial role of neighbors and demesmen in the Athenian household, see Cox 1998, pp. 194-195. DAA 178 was dedicated by Mnesiades kerameus and Andokides; there are known Athenian potters of both names (Wagner 2000, p. 383).

14. Littman 1979; Löhr 2000, pp. 165-167. Cf. the prevalence of commemoration of the patrilineal line of descent (especially fathers and sons) on Archaic Attic gravestones (D'Onofrio 1998, pp. 116-117).

15. Eretria dedication: Löhr 2000, no. 54; $C E G$ 323. Demokydes and
Telestodike: Kron 1996, pp. 157-158; CEG 414. Telestodike made another dedication on her own on Paros (Lazzarini 1976, no. 726; CEG 413), on which the names of her father (Thersiles) and son (Asphalios) also appear.

16. The dowry as daughters' share of inheritance in Athens: Foxhall 1989, pp. 32-43.

17. Of the 13 joint dedications that preserve some indication of motive, 10 (DAA 29, 41, 94, 114, 117, 160, 210 [both dedications], 217 [original dedication], 291, 292 [one of two dedications]) are called aparchai, compared with two designated dekate, or "tithe" (DAA 186, 292 [one of two dedications]). For the significance of aparche and dekate, see Keesling 2003, pp. 6-10. 
The majority of joint dedications from the Acropolis took the same form as the other private dedications of the same period: a single statue with a single dedicatory inscription. Here I examine three Archaic joint dedications-one found built into the Klepsydra springhouse below the Acropolis and two found on the Acropolis-that attest particularly complex forms of collaboration between the dedicators and show the impact that different forms of patronage could have upon the display of Greek sculpture. In each of these three examples, earlier statue dedications were renovated when new dedicators, in one case a son of the original dedicator, added new statues or statuettes and new inscriptions to the original base. The results are additive sculptural groups consisting of statues added to the monument at different times, and in one case statues of drastically different sizes, all with no recognizable thematic relationship to one another apart from their patrons' desire to associate them by placing them on the same statue base. ${ }^{18}$

The first inscribed base for a joint dedication to be examined here dates originally to the Late Archaic period, but was reused in the Hellenistic period in the parapet of the Klepsydra springhouse on the North Slope just below the Acropolis, where it remains in situ today. ${ }^{19}$ The base (Agora I 5517; Fig. 1) originally stood vertically on one of its narrow ends just like an architectural orthostate, an Archaic dedication type similar to examples from the Acropolis. ${ }^{20}$ Most of the dedicatory inscription, written retrograde in a smoothed band near the top edge of the front face of the block and divided over two inscribed lines, has been preserved: [ca. 4-5] $]_{\varsigma} \vdots \dot{\alpha} \nu \varepsilon^{-}$

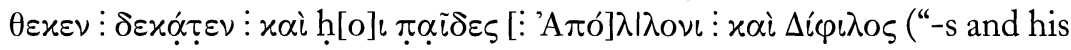
children dedicated a tithe to Apollo, and Diphilos"). The final two words,

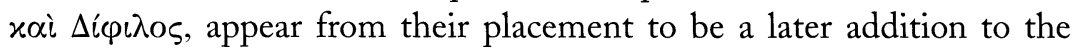
original inscription, though not certainly carved by a different hand. Though B. D. Meritt associated the Klepsydra base with the sanctuary of Apollo Hypoakraios nearby on the North Slope, all of the inscribed dedications found in that sanctuary date to the Roman Imperial period. Since the Klepsydra base, however, was flipped over and reused at least twice even before it was built into the springhouse of the Klepsydra in the Hellenistic period-as indicated by the dowel holes for a bronze statue and the remains of two architectural dowels on the back of the base-it is possible

18. For a distinction between "paratactic" and "syntactic" (narrative or interacting) sculptural groups, see Jacque$\min 1999$, pp. 159-161; cf. Löhr (2000, pp. 153-155), who questions the validity of this distinction.

19. Meritt, Lethen, and Stamires 1957 , p. 79 , no. 24 , pls. 16 (photograph of the inscription) and 25 (drawings); Travlos 1971, pp. 323-331; IG I I $^{3} 950$. For the block's location and the date of its reuse, see Parsons 1943, pp. 239240 , fig. 9 . The date of the inscription, given as ca. 500-480 в.c. in $I G \mathrm{I}^{3}$, cannot be determined with any preci- sion: as Nulton (2003, p. 25) points out, it might date soon after 480 в.c. (cf. Parsons 1943, p. 240).

20. See $D A A 80\left(I G \mathrm{I}^{3} 802\right.$; Kissas 2000, pp. 267-268, no. C48), a pillar base in the shape of an orthostate with a three-line vertical inscription on one of its narrow ends and a single bronze statuette originally attached to its top surface above the inscription. The third line of the inscription (a sculptor's signature?) appears to have been added to the original text recording a joint dedication by Philon, Aristion, Nau-, and Pyrion. 

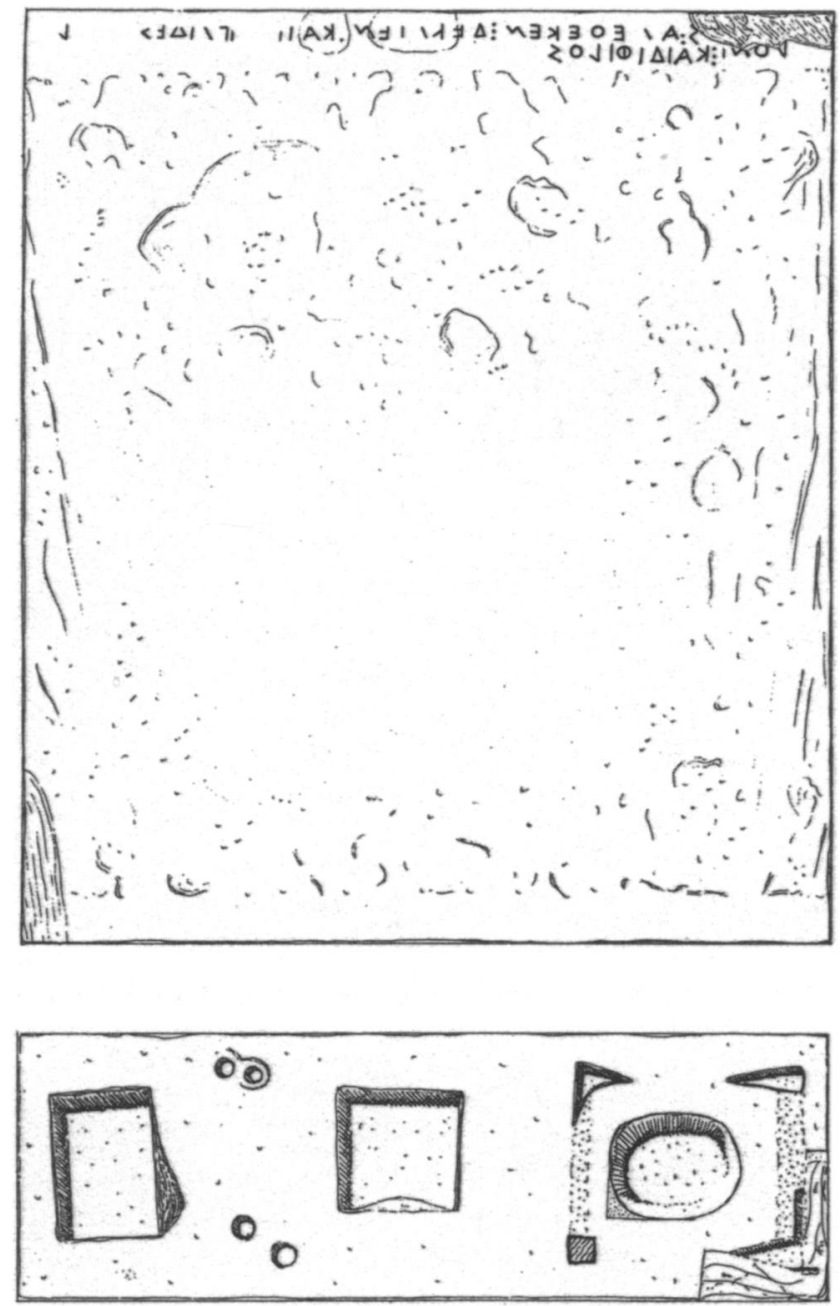

Figure 1. Archaic orthostate base built into the parapet of the Klepsydra springhouse (Agora I 5517). Inscribed face (above) and four cuttings for the attachment of bronze statuettes on the top of the base (below). After Meritt, Lethen, and Stamires 1957, pl. 25

that it traveled from any one of several sanctuaries of Apollo in the vicinity of the Acropolis. ${ }^{21}$

Three small plinth cuttings, two rectangular and one oval, can be seen clearly in the drawing of the Klepsydra base published by Meritt in 1957, reproduced here as Figure 1. All three most likely held the bronze plinths of small bronze statuettes clamped in place by lead soldering, a technique well attested by examples from the Acropolis and elsewhere. The irregularly shaped holes surrounding the oval cutting on the far right can be explained if an oval statuette standing on a rectangular bronze plinth with feet at the corners were attached both beneath the statuette and at the four corners of the plinth. Judging by the sizes and length-to-width proportions of their plinths, it is safe to say only that these lost statuettes were probably standing human figures.

Though previous publications mention only the plinth cuttings for three statuettes, the four round dowel holes located between the two rectangular plinth cuttings (see Fig. 1) also look ancient. Since the three plinth cuttings are equally spaced over the top surface of the base, they may have

21. For the sanctuary of Apollo Hypoakraios, see Travlos 1971, pp. 9195; Nulton 2003. Other likely proveniences include the sanctuary of Apollo Patroös on the west side of the Agora (Travlos 1971, pp. 96-99; Hedrick 1988) and the Pythion, probably to be located near the Ilissos River southeast of the Acropolis rather than on the North Slope (Nulton 2003; cf. Parsons 1943, pp. 233-237; Travlos 1971, pp. 100-103). 


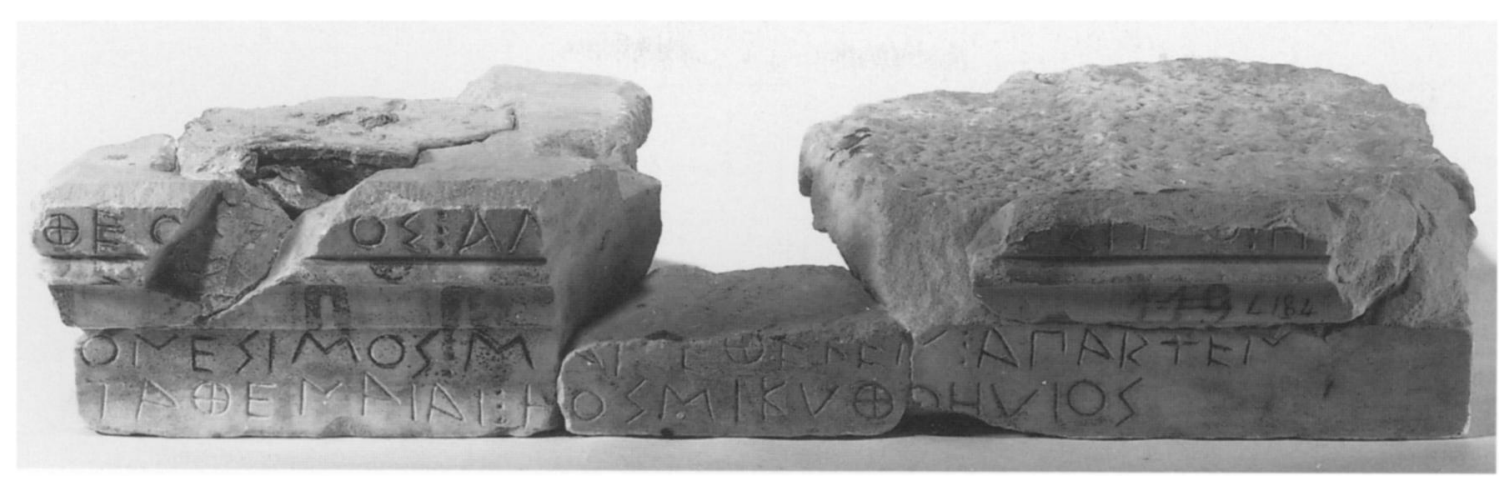

Figure 2. Joint dedication of Onesimos and Theodoros from the Athenian Acropolis (DAA $217=$ Acr. 4184). Courtesy Deutsches Archäologisches Institut, Athens (neg. 1995/121); photo Aehnen

22. For a similar example of a bronze statuette attached to a stone base without a plinth, see the quadruped dedicated by Timarchos and signed by the Early Classical sculptor Onatas (DAA 236; IG $\mathrm{I}^{3} 773$; Kissas 2000, pp. 161-162, no. B99).

23. Cf. $I G \mathrm{I}^{3} 950$ for the suggestion that the three statuettes with plinths represented Apollo, Artemis, and Leto. The Late Archaic dedication

comprised the original dedication, to which a bronze quadruped statuette without a plinth was later added by a second dedicator, Diphilos. ${ }^{22}$ Though the plinth of the statuette on the far left was rotated slightly toward the center, there is no other evidence to suggest physical interaction or thematic coherence in the original group of three statuettes. If, as I suggest, a quadruped (or a horse and rider) were added at some point after the original dedication, the lack of coherence would only have become more pronounced. ${ }^{23}$ This type of monumental sanctuary dedication, consisting of a changing assemblage of individual figures combined on top of the same inscribed base, resembles nothing so much as a cult table of the type placed in front of cult statues to receive offerings, both temporary and permanent, from multiple worshippers. ${ }^{24}$

The inscribed base DAA 217 (Acr. 4184) from the Acropolis consists of four joining fragments of a rectangular pillar capital reconstructed in the storerooms of the Acropolis Museum. Two separate dedicatory inscriptions appear on the front of the base: a two-line inscription on the lower abacus below a painted cymation molding, and a very fragmentary oneline inscription on a second, shorter abacus above the molding (Fig. 2) ${ }^{25}$ Differences in the letter forms of the two inscriptions-e.g., four-barred sigma in the upper inscription, compared with three-barred sigma in the lower one-indicate that they were carved by different letter cutters.

Given that the dedicators' names are Onesimos, son of Smikythos (lower), and Theodoros, son of [One] simos (upper), the natural inference is that the joint dedicators were father and son, and that the son Theodoros's inscription was added to his father Onesimos's original dedication. Since Raubitschek's publication of $D A A 217$, it has been generally accepted that

of Psakythe from the Acropolis $(D A A$ 81; IG $\mathrm{I}^{3}$ 656; Kissas 2000, pp. 100101 , no. B23) consisted of three bronze statuettes on a single base, with the right- and left-hand statuettes both rotated toward the center one.

24. For cult or offering tables in general, see Gill 1991. At Kalapodi (ancient Hyampolis) in Boiotia, an offering table was found inside a temporary cult building constructed after the Persian destruction of the sanctuary in 480 в.с. The table, like the Klepsydra base, resembles an architectural orthostate. Among the offerings found on the Kalapodi offering table was a bronze kouros statuette attached with lead soldering to a cutting (Felsch 1991).

25. In addition to $D A A$, pp. 239241, see Kissas 2000, pp. 123-124, no. B52; $I G \mathrm{I}^{3} 699$ (ca. 500-480 в.c.?). 


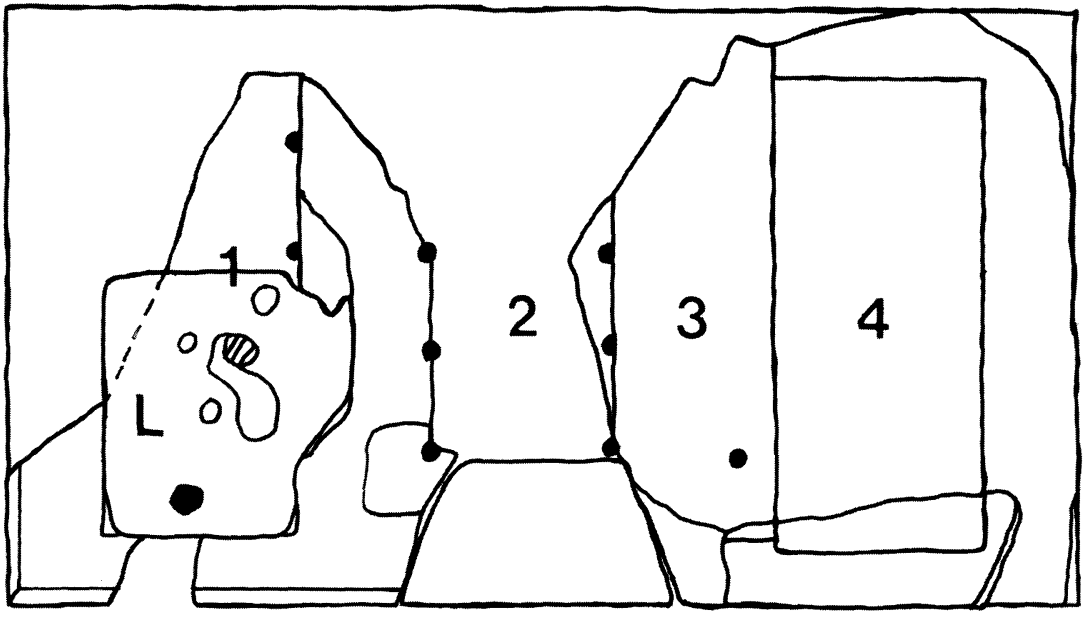

the dedicator Onesimos, son of Smikythos, is identical to the red-figure cup painter Onesimos because few other examples of the name Onesimos can be found in Athens before the Roman period. ${ }^{26}$ In addition to appearing on $D A A 217$, the name of Onesimos Smikythou appears (or can be restored) on a series of eight inscribed marble perirrhanteria dedicated on the Acropolis ( $D A A 349-353,357,358$, and $I G \mathrm{I}^{3}$ 933). Though Raubitschek at one point suggested that the pillar capital $D A A 217$ was damaged in the Persian sack of 480 в.с. and restored after 480 by Onesimos's son Theodoros, the best-preserved, left-hand fragment was found in February 1886 together with 14 marble korai in a large Perserschutt deposit west of the Erechtheion likely to date soon after the Persian sack. ${ }^{27}$ Thus, both inscriptions, and the two phases of dedication they represent, should date before 480 B.C., a result that agrees with the identification of Onesimos with the Athenian vase painter of the same name. It is not possible to determine how long an interval may have passed between Onesimos's original dedication and the second inscription added by his son Theodoros.

The top surface of this base (Fig. 3) is difficult to interpret because it features a series of four cuttings of different shapes and dimensions, apparently for the attachment of four statuettes using different techniques. Cutting 1 , on the far left, a long rectangle with an irregularly shaped extension on its right side, was entirely filled with lead (now broken off at the back). The rounded protrusion (crosshatched in Fig. 3) about halfway between the front and back edges of the cutting almost certainly marks the original location of the foot of a bronze statuette, its bronze plinth completely submerged beneath the lead soldering. A hole in the lead covering the bronze plinth just in front of this protrusion (blackened in Fig. 3) may or may not mark the position of another foot. ${ }^{28}$

Nearly all of the floor of cutting 2 has broken away, but a series of small, round dowel holes used to help lead soldering (now lost) adhere to the sides of the cutting show where the cutting's left and right edges were. Cutting 2 also features a shallow rectangular extension at the front left corner. ${ }^{29}$ The floor of cutting 3 , a long, narrow rectangle with length-towidth proportions of approximately $3: 1$, features a shallow round hole
Figure 3. Joint dedication of Onesimos and Theodoros (DAA 217). Top view showing four cuttings for the attachment of statuettes. C. M. Keesling

26. For the vase painter Onesimos, see LGPNII, s.v. 'Ovท́⿴囗uо 3 ; Robertson 1992, pp. 43-50 (identified as the Panaitios Painter), 117-118; Cook 1997, p. 165 (Onesimos's career dated from the late 6 th century through ca. 480 в.c.).

27. See $D A A$, pp. $247-248$, contradicting p. 462; for the findspot, see Kavvadias 1886, col. 81, no. 5, fig. 2; Lindenlauf 1997, pp. 70, 107-108; cf. Lolling 1890, p. 42, no. 4, and Löhr 2000, pp. 37-38, no. 40.

28. Cf. Kissas 2000, pp. 123-124, no. B52.

29. A similar "extension" for lead soldering appears on the pillar capital DAA 291 ( $I G \mathrm{I}^{3}$ 697; Kissas 2000, pp. 162-165, no. B101). For the function of the round dowel holes along the sides of the plinth cutting, see Raubitschek 1938, p. 143; Kissas 2000, p. 9. 
Figure 4. Joint dedication of Onesimos and Theodoros (DAA 217). Hypothetical section through the pillar capital. C. M. Keesling

30. On another Acropolis base for multiple statuettes, $D A A 81$ (Kissas 2000, pp. 100-101, no. B23), slightly different attachment techniques were used simultaneously. In this case, there is a single dedicator (Psakythe) and a signature of the sculptor Hermippos. The plinth cuttings in the center and on the right feature shallow round nail holes approximately a centimeter in diameter, while the plinth cutting on the left has much smaller holes for nails or for lead soldering around its edges. The statuettes on the left and right were turned toward the center one, suggesting a thematically related group.

31. See, most recently, Keesling 2003, pp. 81-85. The length-to-width proportions of the plinth for the bestpreserved Athena Promachos statuette from the Acropolis, the Athena dedicated by Meleso (NM 6447), are 2.23:1 $(0.118 \times 0.053 \mathrm{~m})$, close to the $2: 1$ proportions of cutting 4 on $D A A 217$.

32. $D A A$, pp. 239-241; $I G \mathrm{I}^{3} 695$ (ca. $500-480$ в.c.?); Kissas 2000 , pp. 114-115, no. B42.

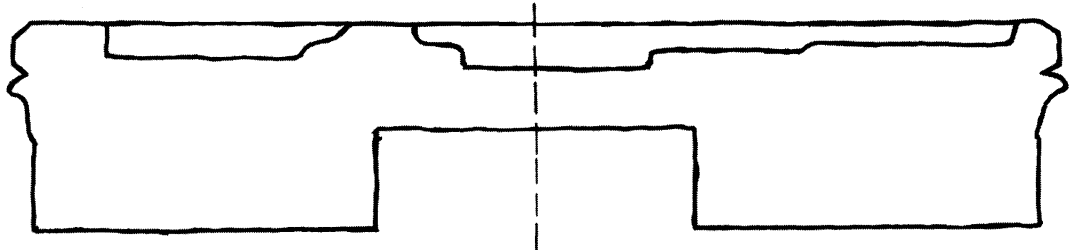

that might have received the end of a nail used to attach a bronze plinth to the cutting. The floor of cutting 4 is shallower and more roughly worked than that of cuttings 2 and 3 , and it is the only plinth cutting on $D A A 217$ whose full dimensions have been preserved $(0.31 \times 0.16 \mathrm{~m})$. The length-to-width proportion of cutting 4 is approximately $2: 1$. Without any evidence for the fastening technique used, it is conceivable that cutting 4 received either a small marble statuette or a bronze statuette on a bronze plinth.

A hypothetical section through $D A A 217$ (Fig. 4) suggests possible reconstructions. This inscribed capital originally rested on top of a thick rectangular pillar as wide or nearly as wide as the capital itself, with a large tenon fitting into the rectangular mortise on the preserved capital's underside. The differences in size, shape, and technique between the cuttings on the top surface suggest that they were not contemporary. ${ }^{30}$ The original dedication by Onesimos might have consisted either of a single statuette in cutting 2 , centered over the supporting pillar, or three statuettes roughly equidistant from one another in cuttings 1,2 , and 4 . In a second phase, corresponding with the dedicatory inscription of Theodoros, a fourth statuette in cutting 3 may have been added.

Alternatively, Theodoros may have replaced one or more original statuettes dedicated by Onesimos on the base in cuttings 1,2, or 4 at the same time that he added another statuette in cutting 3 . The addition of the added weight of a fourth statuette in cutting 3 in a second phase after the original dedication would help to explain why the pillar capital eventually broke apart into two halves, completely shattering cutting 2 . The occasion for Theodoros's dedication may have been damage to one or more statuettes dedicated by his father, or might simply have been the result of Theodoros's intent to complete the dedication or to fulfill his own or his father's vow. Though there is insufficient evidence to reconstruct the types of statuettes dedicated by Onesimos and Theodoros, the long, narrow shapes of all four cuttings find parallels in preserved bronze statuettes representing quadrupeds and striding, attacking Athenas of the "Promachos" type: several contemporary examples of the latter type were found on the Acropolis. ${ }^{31}$ It is even possible that the four statuettes were repeated images, representing the same subject in the same pose.

$D A A 210$, assembled from four fragments found on the Acropolis and now on display in the Epigraphical Museum (EM 6320B + 6392 + $6501+$ 6376 ), is a larger example of the same type of rectangular capital as $D A A$ $217 .{ }^{32}$ Here, two separate dedicatory inscriptions, in this case carved by the same hand, appear on the front and right sides of the capital. The incomplete three-line inscription on the front of the base (Fig. 5) names Chares 


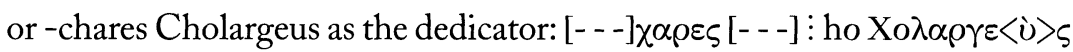

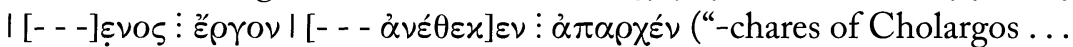
of [his] works ... dedicated first-fruits"). The inscription on the right side

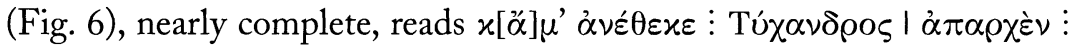
$\tau \dot{\alpha} \theta \varepsilon \nu \alpha i \alpha_{l}$ ("and Tychandros dedicated me, first-fruits to Athena"). Though the inscribed texts give no indication of the relationship between the two dedicators, Tychandros's dedication begins with the conjunction $x \alpha i$, giving the impression that Tychandros added his offering to that of -chares. The top surface of the base (Fig. 7) preserves two plinth cuttings for marble statues. The cutting for the larger statue, on the left, is only partially preserved; the much smaller rectangular cutting added on the right is complete and appears to belong to the dedicatory inscription of Tychandros.

The physical reconstruction of the monument is significant for determining the types of statues the base supported, and also for restoring the main dedicatory inscription. Raubitschek, P. A. Hansen, and the editors of $I G \mathrm{I}^{3}$ all reconstructed the -chares inscription as three hexameter verses divided into three inscribed lines, a restoration based on the assumption that a considerable part of the left end of DAA 210 has been lost. The rectangular mortise for a missing pillar is preserved on the underside of $D A A 210$ (shown in Fig. 7 by the dotted rectangle). ${ }^{33} \mathrm{~A}$ reconstruction with a single supporting pillar would necessitate a minimal, nonmetrical restoration of the text of the inscription. If, on the other hand, the -chares inscription consisted of three hexameters, as it is normally restored, $D A A$ 210 must be reconstructed as the right end of a much larger capital supported by two rectangular pillars, a monument type for which there is at least one good parallel from the Archaic Acropolis, $D A A 196 .{ }^{34}$ In this reconstruction, the statue dedicated by -chares was a long and narrow marble horse, horse and rider, or bovine. Equestrian dedications, both with and without riders, are well attested on the Acropolis in the Archaic period. ${ }^{35}$

The dimensions of extant plinths and plinth cuttings for quadrupeds and horses with riders have length-to-width proportions ranging anywhere between 2:1 and 5:1. The length-to-width proportion of the smaller cutting, for Tychandros's statue, is approximately 3:1 (the cutting measures $0.355 \mathrm{~m}$ long by $0.120 \mathrm{~m}$ wide). If the larger statue, dedicated by -chares, were a horse or a horse with rider having a length-to-width proportion of 3:1, the base should be approximately $1.40 \mathrm{~m}$ long. ${ }^{36}$ One argument against reconstructing the statue dedicated by -chares as a horse with rider rather than some other type of quadruped is the fact that horses with riders were

33. Cf. the square proportions of the plinth cutting for a seated figure on the funerary monument of Anaxilas of Naxos in the Kerameikos Museum (I 388), with dimensions of $0.72 \times$ $0.73 \mathrm{~m}$ (Kissas 2000 , pp. 62-63, no. A29).

34. DAA 196 is another rectangular pillar capital (Raubitschek 1938, pp. 158-160; Kissas 2000, pp. 108-110, no. B35). Its height is comparable to that of DAA 210 (0.198 m, compared to $0.217 \mathrm{~m}$ ); the plinth cutting for a marble statue (probably a horse or a rider) is not fully preserved.

35 . For the preserved marble horses and horses with riders from the Acropolis, see Eaverly 1995; Trianti 1998, pp. 183-188. For equestrian statues in bronze, see Keesling 2003, pp. 89-91.

36. For the dimensions, see Kissas 2000, pp. 114-115, no. B42. Raubitschek (DAA, p. 240) and Kissas (2000, p. 114) both restored a slightly shorter length of ca. $1.30 \mathrm{~m}$ for the base. The 5th-century examples discussed by Mattusch (1988, p. 193) suggest the following dimensions for the quadrupeds dedicated by -chares and Tychandros: $1.15 \mathrm{~m}$ long $(=75 \%$ of $1.53 \mathrm{~m})$ and 1.36 tall $(=89 \%$ of $1.53 \mathrm{~m})$ for the larger one; and $0.266 \mathrm{~m}$ long $(=75 \%$ of $0.355 \mathrm{~m}$ ) and 0.316 tall $(=89 \%$ of $0.355 \mathrm{~m}$ ) for the smaller. 

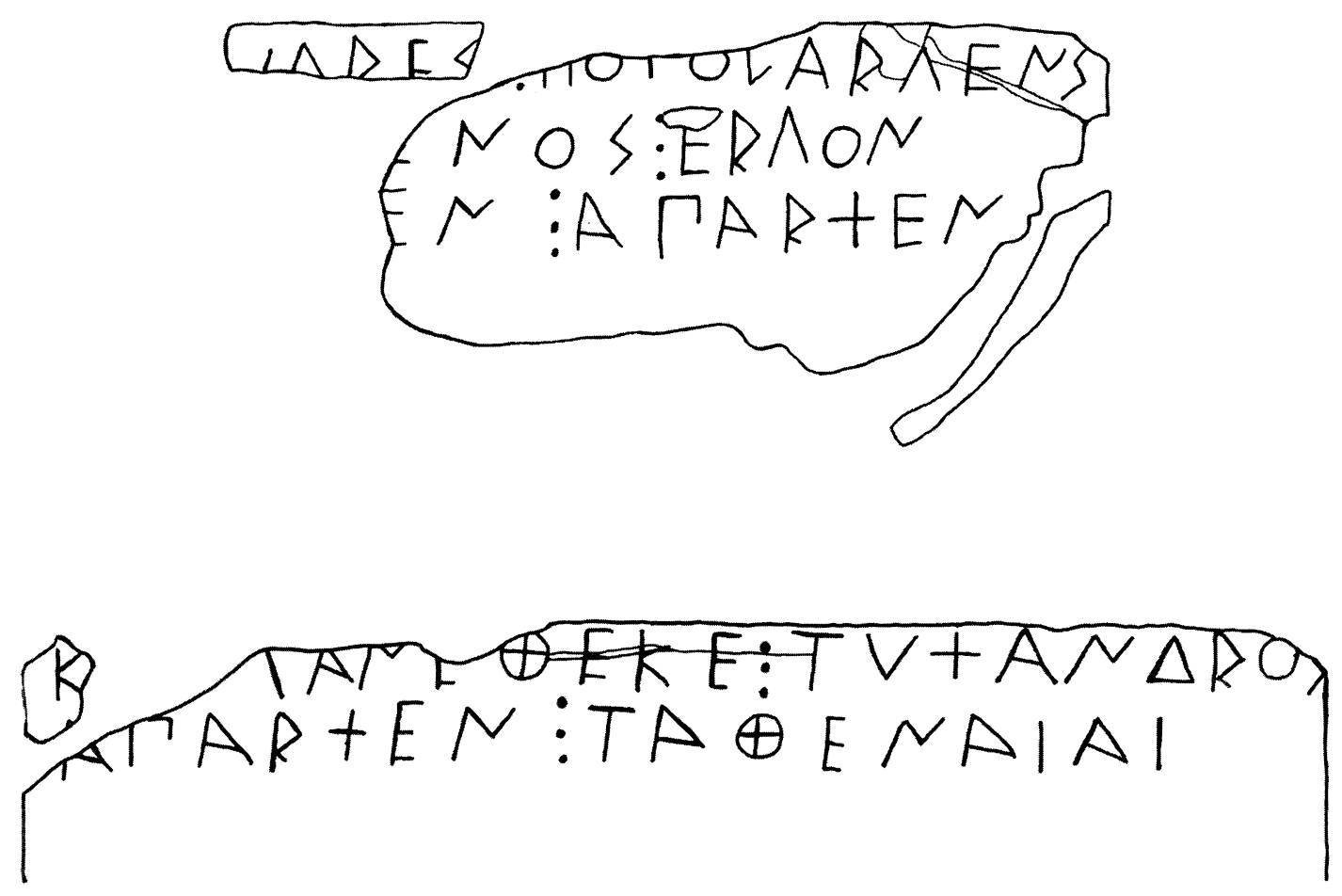

Figure 5 (top). Joint dedication of -chares and Tychandros from the Athenian Acropolis $(D A A 210=$ EM 6320B + 6392 + 6501 + 6376). Dedicatory inscription of -chares on the front of the inscribed base. C. M. Keesling

Figure 6 (center). Joint dedication of -chares and Tychandros (DAA 210). Dedicatory inscription of Tychandros on the right side of the base. C. M. Keesling

Figure 7 (right). Joint dedication of -chares and Tychandros (DAA 210). Top surface of the base showing two plinth cuttings. The small, complete cutting on the right belongs to the dedication of Tychandros; the large, incomplete cutting on the left belongs to the dedication of -chares. C. M. Keesling

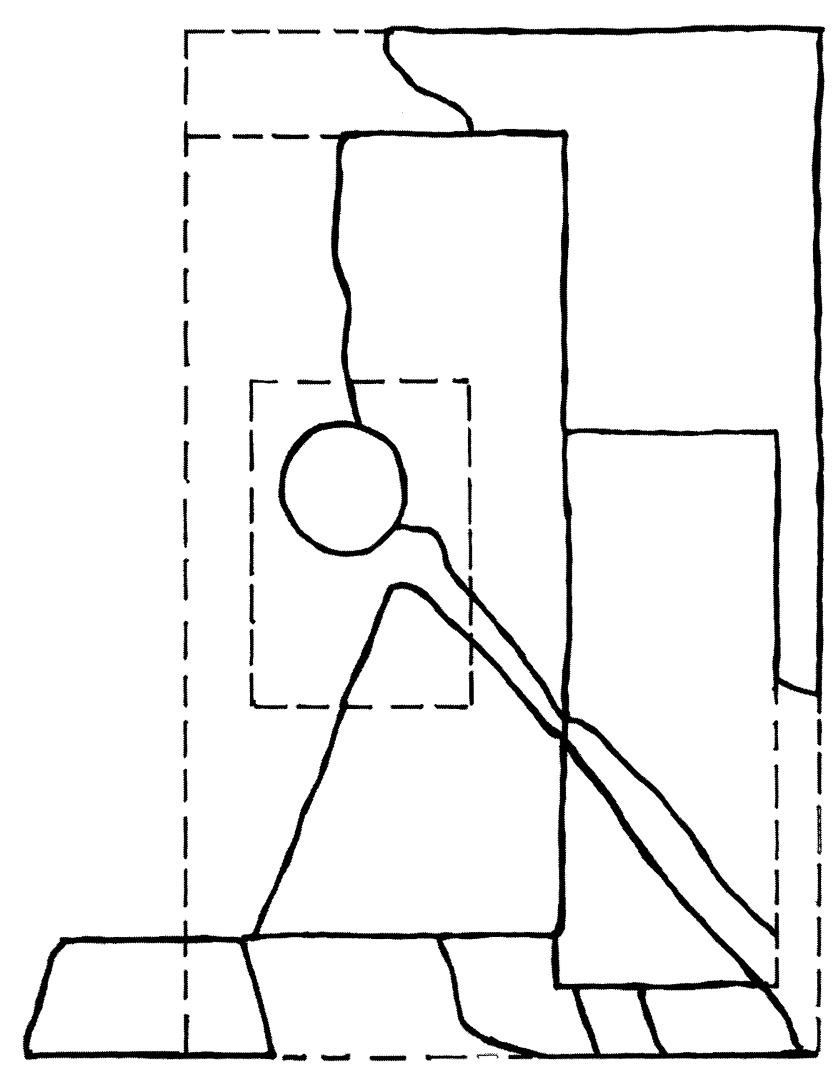




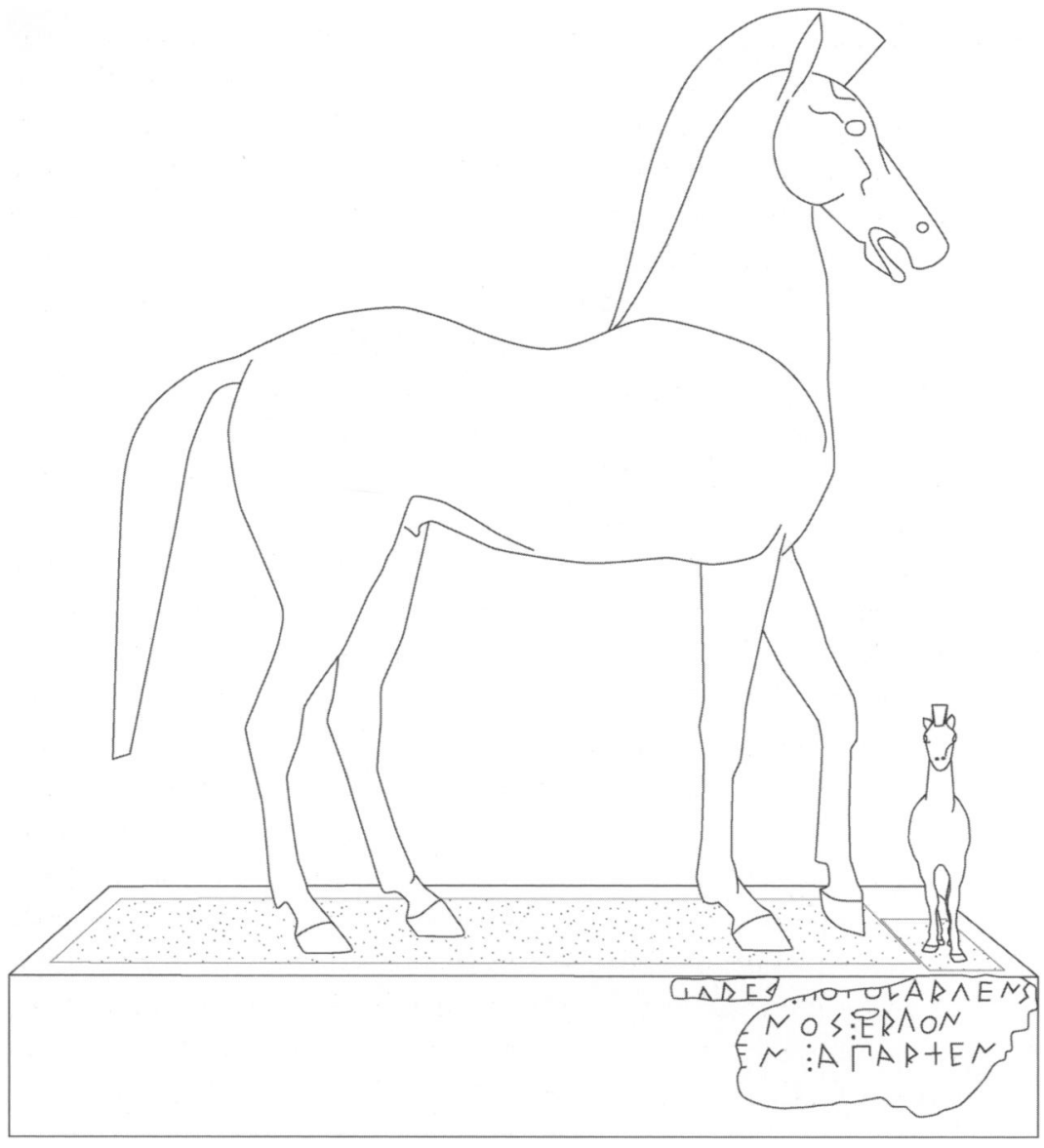

usually inscribed on the narrow end rather than the long side of the base; it also seems unlikely that the two dedicators -chares and Tychandros would have chosen to juxtapose equestrian portraits of such different sizes with one another on the same inscribed base. Both lost statues may on these grounds be restored as horses without riders, as in Figure 8.

The statue dedicated by Tychandros was a much smaller marble quadruped or horse with rider with its dedicatory inscription beneath one of its long sides. Combining the two offerings dedicated separately by -chares and Tychandros on the same inscribed base resulted in the awkward juxtaposition of two marble statues, probably of the same type but of strikingly different sizes. The sole justification for such a sculptural "group" was the desire of -chares and Tychandros to combine their individual offerings on the same inscribed base, either simultaneously or at some point after the original monument of -chares had been dedicated on the Acropolis. Given that both dedications are aparchai, -chares and Tychandros may have placed their offerings on the same base to demonstrate that they both received income from the same source, be it an inheritance or a windfall profit. The difference in scale might mean that Tychandros received less income from this source than did -chares.

The reconstruction of three Late Archaic joint dedications from Athens raises questions about the origins and significance of Greek sculptural groups. We normally think of such groups as a phenomenon characteristic
Figure 8. Reconstruction of the joint dedication of -chares and Tychandros (DAA 210). Courtesy K. E. Rasmussen, Archeographics 
of the Classical period, represented not only by large-scale bronze row groups of thematically linked statues, such as the Athenian Marathon dedication at Delphi or the eponymous heroes in the Athenian Agora, but also by figures depicting mythological events, such as Myron's Early Classical Athena and Marsyas group on the Acropolis. ${ }^{37}$ In the Archaic period, lifesize and over-lifesize familial portrait groups consisting of statues standing on the same base were dedicated in the Samian Heraion (the Geneleos group) and at Didyma. Given the greater scale, however, and the absence of largescale familial portrait groups on the Acropolis before the 4th century B.C., ${ }^{38}$ such dedications do not provide an obvious model for interpreting the Late Archaic groups of small votive statuettes attached to the same base.

If the Klepsydra base, $D A A 217$, or $D A A 210$ included multiple statuettes of the same type or subject, such duplication cannot easily be explained in cultic terms, like the phenomenon of paired or multiple votive images of Demeter, Kore, and other female deities described by Theodora Hadzisteliou Price. ${ }^{39}$ In the case of $D A A 210$, the contribution of two dedicators apparently resulted in duplication of the same sculptural type; in the other two examples discussed here, duplication within groups of four statuettes is also possible. A more convincing parallel is the group of 20 largescale bronze Apollos dedicated by the Liparians at Delphi, commemorating the Liparians' capture of 20 Etruscan ships in a naval battle (Paus. 10.16.7). Though the date of this dedication is uncertain, it is probably roughly contemporary with the three votive statuette groups from Athens. ${ }^{40}$ Such nonrational "votive groups" may have been common in the Archaic period, and they continued to be dedicated in Greek sanctuaries alongside the lifesize bronze row groups typical of the Classical period.

Though the Liparian dedication at Delphi appears to have been unique for its size and prominence, private, familial dedications of multiple divine images are attested in the Early Hellenistic period by a dedication of a group of eight marble statuettes representing Demeter, Kore, and Hades by members of the same family over the course of 100 years at Kyparissi on Kos. ${ }^{41}$ A Late Archaic or Early Classical relief from Athens (NM 29) depicting two identical armed Athenas, considered by Hadzisteliou Price and M.-A. Zagdoun to be a divine image duplicated for cultic reasons, might in fact have been a joint dedication, though it lacks both an archaeological find context and an inscription..$^{42}$ This form of sculptural patronage with its origins in the Archaic period deserves further study.

37. For row groups of the 5 th century в.c., see Ioakimidou 1997; Mattusch 1994. Cf. Schanz (1980, pp. 7077), who treats the Tyrannicides in the Athenian Agora as a "dramatic" group, a type she distinguishes from both row groups and groups with physically interlocking figures.

38. Lack of 5th-century familial portrait groups on the Acropolis: Keesling 2003, p. 106. The early4th-century Konon and Timotheos dedication on the Acropolis, which featured portraits of Konon and his son Timotheos seen by Pausanias (1.24.3), was originally dedicated by Konon; at a later date Timotheos added his name to his father's (Löhr 2000, pp. 76-77, no. 86). It remains unclear from the preserved portions of the base whether or not the group included any additional statues, and which statues were added by Timotheos.

39. Hadzisteliou Price 1971.

40. Delphi Liparian group: Ioakimi- dou 1997 , pp. $47-50$, no. 5 , pp. $148-$ 151; CEG 2831.

41. Kabus-Preisshofen 1975; Kron 1996, pp. 149-150.

42. See Hadzisteliou Price 1971; Zagdoun 1989, p. 46, no. 56, pl. 1:3. The latter suggests that the image of Athena was duplicated "dans un désir de rendre plus intenses à la fois l'apparition divine et la valeur de l'offrande qui lui est addressée." The relief was originally published by Mylonas (1891). 


\section{PATRONS, SCULPTORS, AND THE INTRO- DUCTION OF IONIC SCRIPT TO ATHENS}

Perhaps the most direct example of the effect private patrons had upon Athenian art comes not from the Archaic period, but from the mid-5th century в.c. During the roughly 50-year period between the end of the Archaic funerary monuments in ca. 480 and the widespread production of High Classical grave monuments with reliefs beginning in ca. 430 в.c., deceased non-Athenian individuals continued to be commemorated with inscribed stelai, some of them with sculptural decoration, in the Kerameikos and other cemeteries. ${ }^{43}$ The majority of these "patrons" came from the Cyclades or Ionia, and the inscriptions on their monuments almost always featured the Ionic long vowel eta $(\mathrm{H})$, not officially adopted in Athenian decrees until the archonship of Eukleides in 403/2 в.C. The use of eta on several of these inscribed gravestones initially led to their being mistakenly dated to the 4th century в.c. ${ }^{44}$ Whatever the cause for the 5 th-century gap in Athenian funerary monuments, it appears that the traditions of non-Athenians continued to be accommodated, and that individuals who died abroad continued to be considered particularly worthy of monumental commemoration as they had been in Archaic Athens. ${ }^{45}$

Letter forms, spelling, and the use of particular words or formulas in inscriptions still constitute a relatively untapped source of information about patronage in Archaic Athens due to lingering uncertainties about their significance. It is clear that several Archaic funerary monuments found in Athens and Attica commemorated non-Athenians, identified as such by their ethnics, and that most of those commemorated in this fashion came either from the Cyclades or from Ionia. The inscriptions on some, but not all, of these monuments feature letter forms native to East Greek alphabets, such as four-barred sigma, dotted theta, and gamma written as a vertical stroke with a horizontal stroke at the top. They also feature the use of eta and omega to represent long vowels and psilosis, the omission of the aspirate represented in the Attic alphabet by the character heta $(\mathrm{H}){ }^{46} \mathrm{It}$ is clear that sculptors from the Cyclades and Ionia were working in Athens in the Archaic period, as indicated by the signatures of Archermos of Chios on Acropolis dedications and of Aristion of Paros on several funerary monuments, including the kore of Phrasikleia. ${ }^{47}$ In the scholarship on

43. See Stears 2000, p. 31, where the resumption of sculptural gravestones for Athenians is also dated as early as ca. 450 B.c. Funerary inscriptions possibly datable between ca. 480 and ca. 430 в.c.: $I G \mathrm{I}^{3} 1236 \mathrm{bis}, 1237$, 1237bis, 1250, 1254, 1270, 1280, 1281, 1282, 1300, 1301 (deceased from Chersonese), 1302-1305, 1323-1325, 13321335, 1341, 1342 (Andros), 1345 (Chios), 1346 (Knidos), 1348 (Corinth), 1351 (Lampsakos), 1353 (Lesbos), 1355 (Messenia), 1356 (Miletos), 1358 (Pallene), 1359 (Pallene), 1360 (Phaselis), 1370 (Stagira), 1371 (Syracuse), 1376, and 1377-1379 (Torone).
44. E.g., Harrison 1956, pp. 38-39 (Kaletor of Teos). For the lost Athenian decree of Archinos calling for the adoption of the Ionic alphabet, see Theopompos, FGrH $115 \mathrm{~F} 155$, discussed by Woodhead (1981, pp. 16-19).

45. Commemoration of death abroad in Archaic funerary monuments: Sourvinou-Inwood 1995, pp. 285-290. An Archaic example of the commemoration of an Athenian who died abroad is the inscribed stele for Chairion from Eretria ( $I G \mathrm{I}^{3}$ 1516), which identifies him as "Chairion the Athenian, of the Eupatrids" (discussed in Keesling 2003, pp. 183-184).
46. See, in general, Threatte 1980, pp. 31-43. For an early-5th-century inscription from Marathon with Ionic gamma, see Vanderpool 1984.

47. Archermos of Chios: see, in addition to $D A A 3$, two bases from the Acropolis signed by unknown Chian sculptors $\left(D A A 9\left[I G \mathrm{I}^{3} 756\right]\right.$ and Kreeb 1986 [ $I G \mathrm{I}^{3}$ 830bis]). Aristion of Paros: $I G \mathrm{I}^{3} 1261$ (Phrasikleia), 1208 (funerary monument for Antilochos), and 1211 (funerary monument for Xenophantos, son of Kleiboulos). For Cycladic influence upon the form and decoration of votive column monuments on the Acropolis, see McGowan 1997. 
Archaic Greek sculpture, the tyranny of Peisistratos and his sons, during which the family's personal relationship with other tyrants such as Polykrates of Samos led to the emigration to Athens of East Greek poets, has been suggested as the historical occasion for the migration of East Greek sculptors to Athens. ${ }^{48}$

Didier Viviers has argued not only for the Ionian origin of one particular sculptural workshop in Archaic Athens-that of Endoios, Philergos, and Aristokles-but also for close links between these sculptors and East Greek patrons living in Athens. ${ }^{49} \mathrm{He}$ cites the use of Ionic letter forms and spelling on statue bases with Endoios's and Philergos's signatures as evidence that they were Ionians more accustomed to the Ionic than to the native Attic alphabet. The link with East Greek patrons in Athens comes from the presence of the signatures of Endoios, Philergos, and Aristokles on several of the known funerary monuments for deceased individuals identifiable as East Greeks by their ethnics or by inscribed epigrams alluding to their foreign origins. ${ }^{50}$ Anna Maria D'Onofrio attempts to expand the list of East Greek patrons further through prosopographic conjectures. ${ }^{51}$ Angeliki Andreiomenou, in her publication of a newly discovered grave relief for a Boiotian from Akraiphia signed by Philergos, further suggests that Philergos and other Ionian sculptors working in Attic workshops exerted considerable influence upon not only the style and format of Archaic funerary monuments, but also upon letter forms, spelling, layout, punctuation use, and word choice in metrical epigrams. She also expands the circle of attributions to the workshop identified by Viviers to include unsigned works such as the so-called "Brother and Sister" stele in the Metropolitan Museum of Art. ${ }^{52}$

Viviers' contention that sculptors in Archaic Athens normally carved their own signatures on statue bases, crucial to his identification of an East Greek sculptural workshop operating in Athens, depends upon his identification of hands in inscriptions. ${ }^{53}$ Though hand identification has been used successfully as a method of analysis by Stephen Tracy for Athens in the Hellenistic period, Attic epigraphists have routinely denied the possibility of identifying hands in Archaic inscriptions because the lack of standardization in letter forms and letter heights makes it too difficult to identify features particular to an individual hand. ${ }^{54}$ As Jeffery herself admitted of her attempt to identify the "masons" who carved Archaic Attic funerary

48. See, e.g., Richter 1961, p. 37 ("Such Ionic influence was of course natural in the Peisistratid era and is observable in Attic sculpture in general"); Immerwahr 1990, p. 181 ("The pressures leading to Ionian influence in the late sixth century clearly came from the Ionians brought to Athens by the Peisistratids"); and Tölle-Kastenbein 1992, pp. 137-138. Glowacki (1998, pp. 84-85), however, points out that Cycladic or Ionian "influence" is evident on the Acropolis already in the first quarter of the 6th century B.C. ("Although it must be kept in mind that all of these objects could have been brought to the Acropolis by a small number of 'private' dedicants, either islanders or Athenian travelers, their presence is suggestive of an 'Ionian' quality in the patronage and art of the early sixth century Athenian sanctuary"). Raubitschek's hypothesis ( $D A A$, p. 16) that the sculptor Pythis who signed $D A A 10$ and 90 was an Ionian who shipped his works ready-made to Athens has been weakened by the discovery of a third statue base with Pythis's signature near Porto Raphti in Attica ( $I G \mathrm{I}^{3} 1018$ ter). For the tradition that Hipparchos brought Anakreon of Teos and Simonides of Keos to Athens, see Slings 2000, pp. 60-66. 49. Viviers 1992.

50. E.g., Viviers 1992, pp. 103-114 (Leanax of Samos, signed by Philergos), 116-124 (the Carian Tyr-, son of Skylax, signed by Aristokles).

51. D’Onofrio 1998, pp. 113-116.

52. Andreiomenou 1999, esp. pp. $95-105 ; 2000$, esp. pp. 96-106.

53. Viviers 1992, pp. 21-51; cf. Jeffery (1962, pp. 151-152), who cited examples in which the same "mason" inscribed monuments signed by different sculptors.

54. See esp. Tracy 1984; 1990, pp. 2-4; see also Dow 1975, p. xiii. 
inscriptions, she could not be certain that some of the different masons were individual hands rather than variations produced by the same craftsman; this type of stylistic grouping without certainty that the work can be attributed to a single individual has elsewhere been called the identification of "analytical individuals." 55 Raubitschek and Jeffery attempted independently to identify hands on the Acropolis dedications of the 6th and 5th centuries B.c. with differing results: of the 13 hands and four possible hands identified by Raubitschek and the 15 hands and three possible hands identified by Jeffery, only six are identical. ${ }^{56}$ Another complicating factor is the possibility that texts may have been drawn on the stone by one hand and the inscription cut by another: this has been confirmed by Viviers, who found traces of preliminary incision beneath the inscribed letters on the funerary monument of Tyr- the Carian signed by Aristokles from the Kerameikos. ${ }^{57}$

Any comparison between the Archaic funerary monuments from Athens and the dedications is not as simple as it seems. In the traditional chronologies for Archaic Athenian sculpture and inscriptions, the funerary and votive monuments from both Athens and Attica are not strictly contemporary. Instead, the bulk of the funerary monuments have been dated earlier than the bulk of the dedications. Jeffery published her catalogue of inscriptions on funerary monuments before the publication of a kouros head from the Kerameikos extended the dates for the production of funerary sculpture downward to ca. 480 в.c. Consequently, she dated all of the inscriptions before ca. 500 B.c., Richter's date for the end of the Archaic funerary sculpture series. ${ }^{58}$ The one epigraphical criterion Jeffery consistently used to explain why the majority of the inscribed funerary monuments should date before the majority of the Acropolis dedications in her chronology is letter height: the funerary inscriptions on the whole feature taller letters than the dedications. ${ }^{59}$ Though Jeffery's terminus ante quem of ca. 500 and her use of letter height as a chronological (as opposed to a generic) marker may be questionable, the result is consistent with the lack

55. Redman 1977.

56. Raubitschek's identifications appear in individual catalogue entries and in $D A A$, pp. 436-437; Jeffery's appear only in the individual entries in $I G \mathrm{I}^{3}$. The six overlapping hand identifications are the following: (1) $D A A$ 94 (signed by Hegias) and the Salamis decree ( $I G \mathrm{I}^{3} 1$ ); (2) DAA 58 (signed by Euthykles) and the Hekatompedon decree (IG $\left.\mathrm{I}^{3} 4\right)$; Immerwahr (1990, p. 94) adds a fragmentary inscription of unknown type from Piraeus $\left(I G I^{3} 242\right)$ and the first epigram on the Monument of the Persian War epigrams ( $I G$ $\left.\mathrm{I}^{3} 503 / 4\right)$, all attributed to the "Hekatompedon Master"; (3) DAA 85 (signed by Kalon of Aigina), 86, 87; (4) $D A A$
349-353, 357, 358 (all marble perirrhanteria dedicated by Onesimos); Jeffery adds another fragment of a perirrhanterion, $I G \mathrm{I}^{3}$ 933; (5) DAA 112,369 , the Tyrannicides base in the Athenian Agora ( $I G \mathrm{I}^{3} 502$ ), and the Leagros dedication in the Agora $\left(I G \mathrm{I}^{3}\right.$ 951); (6) $D A A 298$ and $I G \mathrm{I}^{3} 1018$ (both herms signed by Euphron of Paros).

57. Viviers 1992 , pp. 116-124; Kissas 2000, pp. 70-71, no. A41. Other possible examples have been identified by Harrison (1956, pp. 38-40) and Jeffery (1962, pp. 120-121): "it might be suggested that no. $9\left(I G \mathrm{I}^{3} 1211\right)$ is the work of one mason $(\mathrm{C})$, whose hand may perhaps be traced on other bases ... and who sometimes drafted (in paint? in charcoal?) an inscription which an indifferent letterer in the same workshop-Mason B-then cut."

58. See Richter 1961, pp. 37-39, where it is also suggested that Peisistratos might have been responsible for the post aliquanto sumptuary law. The "gap" between the sculptural and epigraphical chronologies has been noted by Engels (1998, pp. 103-104).

59. Cf. Threatte's (1980, p. 5) remarks on the "lower standard of orthography" on funerary monuments, "whether because of carelessness or semi-literacy on the part of the stonecutter or the person responsible for preparing his copy (the purchaser?)." 
of overlap in clienteles and sculptors between the two major genres of private commemorative monuments in Archaic Athens.

Despite D'Onofrio having recently collected 16 possible examples of name matches between the clienteles of Archaic funerary monuments and dedications in Athens, the lack of patronymics for two-thirds of the individuals named on funerary monuments significantly weakens any argument for identity with the dedicators of votive monuments, or even for family relationships.$^{60}$ On the contrary, it seems remarkable how few prosopographic links can be found between the patrons of funerary monuments and dedications in Athens in the Archaic period, as well as how little overlap there is between the sculptors who signed them: only Endoios, Philergos, and Aristokles are known to have signed both types of monuments. ${ }^{61}$

The use of Ionic letter forms and spelling on Archaic and Early Classical (ca. 480-450 B.c.) dedications in Athens requires a different explanation than the presence of East Greek patrons. In contrast to the considerable numbers of Archaic and 5th-century funerary monuments commemorating individuals with foreign ethnics, ethnics identifying patrons as non-Athenian hardly ever appear on the dedications of the same period. ${ }^{62}$ A distinction needs to be made between the adoption of Ionic letter forms, such as four-barred sigma, and Ionic spelling, represented by the use of eta. ${ }^{63}$ Though it is probable that East Greek craftsmen introduced fourbarred sigma and other letter forms to Athens over the course of the Late Archaic and Early Classical periods, the idea that the four-barred sigma was officially adopted in Athenian state documents in the 440s is an inference from extant inscriptions on stone. On the other hand, the official change from the Attic to the Ionic alphabet in 403/2 B.c. in decrees and

60. D’Onofrio 1998 , pp. 110-113, 120-121 (list of 61 names on funerary monuments, 22 with a patronymic). Alkimachos, son of Chairion, dedicated $D A A 6$ (IG $\mathrm{I}^{3} 618$, ca. $520-510$ в.c.?, but a later date is possible), and a deceased named Alkimachos (no patronymic) was commemorated by $I G \mathrm{I}^{3}$ 1234 (ca. 500 в.c.). The name Alkimachos reappears between ca. 470 and 420 B.c. as a kalos name on Attic redfigure pottery $\left(A R V^{2}\right.$, p. $1698 ;$ Adden$d a^{2}$, p. 392; Immerwahr 1990, p. 167, no. 1162; $L G P N I I$, s.v. 'A $\lambda x i \mu \alpha \chi 0 \varsigma$ 3, 5-7; Brenne 2000, p. 33) and in a casualty list of $459 / 8$ ( $\left.I G \mathrm{I}^{3} 1147 \mathrm{bis}\right)$. The recurrence of the name in two different contexts in the 5 th century casts some doubt upon the association of the two Archaic monuments with a single individual (cf. D'Onofrio 1998, p. 110). D'Onofrio (1998, p. 111) also includes in her list of name matches Lyseas $\left(I G \mathrm{I}^{3} 1257\right)$ and Aristion $\left(I G \mathrm{I}^{3} 1256\right)$, commemorated by funerary stelai found at Velanideza in Attica, and the [Lys] eas and Aris[tion] who dedicated $D A A$ 8, but Raubitschek ( $D A A$, pp. 1315) restored these names on the Acropolis dedication specifically to create the name match with the funerary monuments. Other restorations are certainly possible.

61. Endoios: $D A A 7 ; I G \mathrm{I}^{3} 1380$ (stele of Lampito); $I G \mathrm{I}^{3} 1214$ (Neilonides base); see also Keesling 1999; Marx 2001. Philergos: DAA 7; IG $\mathrm{I}^{3}$ 1365 (Leanax of Samos); the funerary stele from Akraiphia published by Andreiomenou $(1999,2000)$. In addition to signing the funerary monuments $I G$ $\mathrm{I}^{3} 1218$ (Xenophantos, son of Sophilos), 1229 (Oinanthe), and 1256 (stele of Aristion), Aristokles signed a lost dedication from Pallene in Attica ( $I G \mathrm{I}^{3}$ 1009). Though only five dedications from Athens and Attica not belonging to the Acropolis preserve the names of sculptors, two of these sculptors (Pythis $\left[I G \mathrm{I}^{3}\right.$ 1018ter] and Euphron [IG $\mathrm{I}^{3}$ 1018]) also signed Acropolis dedications. There are three Archaic Attic gravestones for individuals named Xenophantos: $I G \mathrm{I}^{3} 1211$ (son of Kleiboulos, ca. 530-520 в.c.); 1216 (ca. 525-500 в.c.); and 1218 (son of Sophilos, ca. 510 в.c.; discussed in Viviers 1992, pp. 125-129).

62. Exceptions: IG $\mathrm{I}^{3} 1006$ (Aristodamos of Metapontum, from Eleusis, ca. 500-475 в.c.); and DAA 76 (Phayllos of Kroton), 252 (-theos of Sikyon), and 297 (dedicated jointly by Aristomache and Charikleia, daughters of Glaukinos of Argos).

63. On the adoption of Ionic letter forms and spelling in Athenian epigraphy, see, in general, $D A A$, pp. 447448; Threatte 1980 , pp. 33-51; Immerwahr 1990, pp. 78, 108, 179-182; Threatte 1996, pp. 679-680. 
TABLE 1. FOUR-BARRED SIGMA IN DEDICATIONS ON STONE, DOWN TO CA. 450 B.C.

\begin{tabular}{lcc}
\hline$I G I^{3}(D A A)$ & Spelling/Usage Context & Date $\left(I G I^{3}\right)$ \\
\hline $683(3)$ & mixed & ca. $510-500$ \\
1018 ter & $?$ & ca. $510-500$ \\
$763(7)$ & mixed & ca. $500-480$ \\
$764(70)$ & Attic & ca. 500 \\
$805(308)$ & Attic & ca. $500-480$ \\
$837(294)$ & Ionic & ca. $480-470$ \\
1018 & Ionic & ca. $475-450$ \\
$857(298)$ & Ionic & ca. $470-450$ \\
$858(297)$ & Ionic & ca. $470-450$ \\
859 bis $(117)$ & Attic & ca. $470-450$ \\
$941(355)$ & Attic & ca. 470 \\
$875(175)$ & Attic & ca. 450 \\
$876(136)$ & mixed & ca. 450 \\
\hline
\end{tabular}

other state documents-including the use of eta-is both externally attested and supported by the evidence of extant inscriptions. ${ }^{64}$

Four-barred sigma and eta in fact show different patterns of adoption on dedications from Athens. As Table 1 shows, before ca. 450 B.c. fourbarred sigma was just as likely to appear within the context of inscriptions that are otherwise purely Attic in their letter forms and spelling (those marked "Attic" in the table) as it was to appear either in pure "Ionic" inscriptions or in mixed Attic-Ionic inscriptions. What this pattern suggests is that for both the letter cutters of dedicatory inscriptions and the patrons of dedications, the use of four-barred sigma was not considered inconsistent with the native Attic alphabet. The evidence of the ostraka found in the Athenian Agora supports this interpretation. As Mabel Lang has found, the small percentage (9-13\%) of writers of ostraka in the 480 s and 470 s B.c. who used four-barred sigma used it idiosyncratically, "as a variation on the regular [three-barred] sigma to represent sounds perceived by at least a small part of the writing population to be different." ${ }^{65}$ By the end of the 5 th century B.c., four-barred sigma had already become the norm in Athens: the latest ostraka, dating between ca. 417 and 415, show no other forms of this letter.

The long vowel eta may be a more reliable marker of the work of letter cutters trained in the Cyclades or Ionia. A list of examples of eta on dedi-

64. Four-barred sigma not found in Athenian state documents inscribed on stone after 443/2 в.c.: Meiggs 1966, p. 93; Walbank 1974, p. 168. Official change from the Attic to the Ionic alphabet: Threatte 1980, pp. 26-27. The principal challenge to Meiggs's and Walbank's claim that the fourbarred sigma was officially adopted in Athens in the 440s B.c. comes from Chambers, Gallucci, and Spanos (1990), who find three-barred sigmas in the inscription recording an alliance between Athens and Egesta $\left(I G \mathrm{I}^{3} 11\right)$, which they down-date from $458 / 7$ B.c. (the archonship of Habron) to $418 / 7$ B.C. (the archonship of Antiphon). Three-barred sigma continues to appear in dipinti on Athenian vases until ca. 420 в.с. "and sporadically thereafter" (Immerwahr 1990, p. 179).

65. Lang (1982, pp. 80-83) identified three specific situations in which four-barred sigma was used on the Agora ostraka: to mark the end of a word or word group, to combine with chi $(\mathrm{X})$ to produce the double consonant later represented by $\Xi$, and to precede a dental $(\Theta$ or $\mathrm{T})$. Though Lang dated the earliest group of Agora ostraka to the 480s, Brenne (2000, pp. 37-47) shows, using the ostraka found in the Kerameikos, that some should date to the 470 s. 
TABLE 2. ETA IN DEDICATIONS ON STONE, DOWN TO CA. 450 B.C.

\begin{tabular}{lcc}
\hline$I G I^{3}(D A A)$ & Spelling/Usage Context & Date $\left(I G I^{3}\right)$ \\
\hline $800(191)$ & mixed & ca. $490-480$ \\
$837(294)$ & Ionic & ca. $480-470$ \\
1018 & Ionic & ca. $475-450$ \\
$857(298)$ & Ionic & ca. $470-450$ \\
$858(297)$ & Ionic & ca. $470-450$ \\
$859(140)$ & Ionic & ca. $470-450$ \\
$865(46)$ & mixed & ca. $460-450$ \\
$876(136)$ & mixed & ca. 450 \\
953 & Ionic & ca. 450 \\
\hline
\end{tabular}

cations from Athens and Attica down to ca. 450 в.c. appears in Table 2. Though the sample is relatively small, it is noteworthy that eta occurs in combination with other features of Ionic spelling and Ionic letter forms, more often than not in inscriptions written in "pure" Ionic script, rather than where Attic and Ionic features are mixed. In contrast, on the ostrakawhich there is no reason to doubt were written by Athenian citizensonly a single eta appears on the over 1,000 examples from the Agora dated to the 480 s and 470 s B.c. ${ }^{66}$ Unlike four-barred sigma, eta seems not to have become common among the writers of ostraka until the last quarter of the 5th century в.C., when all of the Agora ostraka show the use of eta to represent the long vowel.

What the mixed Attic-Ionic alphabet on some dedications before ca. 450 в.c. may reflect is an attempt by the craftsmen who carved the inscriptions to mediate between their own training in Ionic spelling and the wishes of Athenian dedicators. Instances of corrections from Ionic into Attic spelling support this interpretation; I can find no corresponding 6thor 5 th-century examples of corrections in the opposite direction, from Attic spelling into Ionic. Corrections were in general avoided on the Acropolis dedications, and most of the corrections that were made resulted from causes other than confusion arising from the introduction of Ionic spelling. Instead, dittography, divergence from normal formulas, and the desire to adjust letter spacing produced the majority of the recognizable corrections. ${ }^{67}$ On the Late Archaic pillar base $D A A 258$, however, the letter cutter first carved the initial letter epsilon to spell the name of the fe-

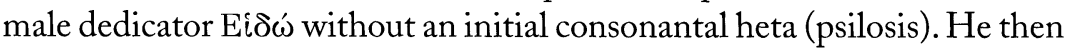

66. Lang 1982; Agora XXV, p. 13. Though taken by Havelock (1982, pp. 198-201) as evidence that Athenian citizens used professional scribes to write ostraka for them, the hoard of 190 ostraka against Themistokles written by only 14 different hands that was found by Broneer (1938, pp. 228-243) on the North Slope of the Acropolis remains exceptional: the ostraka appear to have been thrown into a well and never used in an actual ostracism. Otherwise, the diversity of the writing on ostraka suggests that citizens either wrote their own or had someone else write them on an informal basis (Phillips 1990, p. 136).

67. DAA 246 (the dedication of Hippotherides of Acharnai) shows both an uncorrected dittography and a corrected spelling mistake (Vanderpool 1970, pp. 45-46); for a similar case, see the Archaic gravestone $I G \mathrm{I}^{3} 1260$ ( $C E G$ 72; SEG XL 39; the significance of the correction was pointed out by Martin [1990]). On DAA 53 (dedication of Smikros and his children), the end of the second line as it was originally inscribed was erased and recarved to increase the spacing between the letters (visible in the photographs in $D A A$, p. 54). 


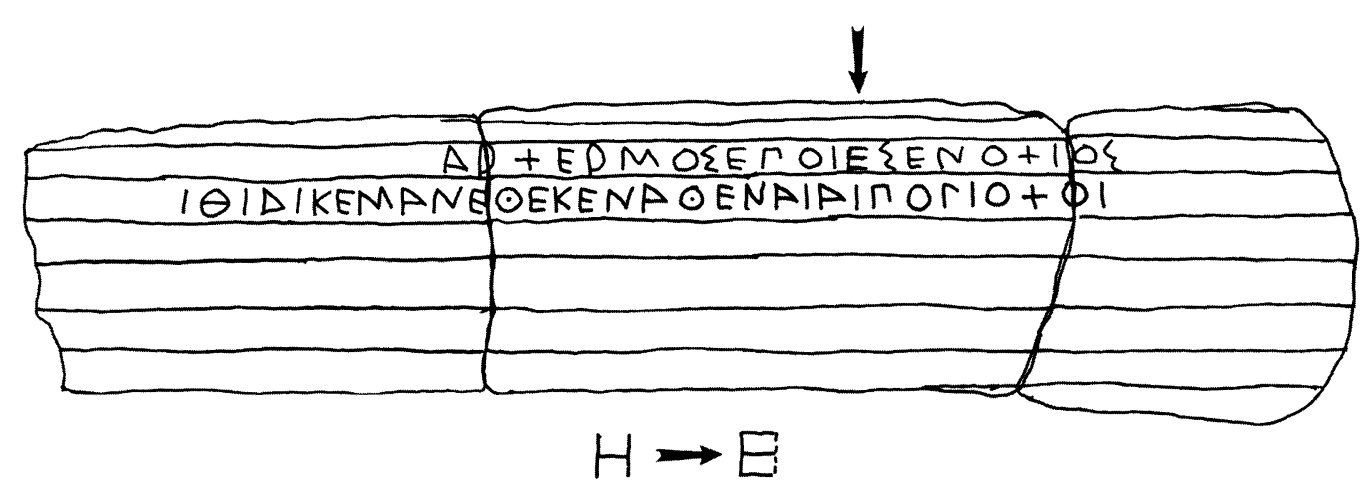

corrected the initial epsilon to a heta. The resulting inscription in the Attic

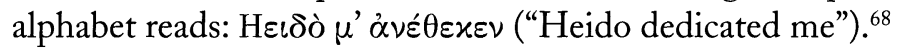

On another Late Archaic dedication from the Acropolis, the votive column base $D A A 3$ dedicated by a woman named Iphidike and signed by the Ionian sculptor Archermos of Chios, the letter cutter originally carved an eta in the verb ह่ $\pi$ oin $\sigma \varepsilon v$ in the sculptor's signature, but later corrected the eta to an epsilon to conform with Attic spelling conventions (Fig. 9). ${ }^{69}$ In addition to the correction, the lack of consonantal heta before the article $o$ in the signature and the compact, squarish appearance of the lettering also point to the work of a letter cutter trained in Ionia. Though the dedicator Iphidike has often been assumed to be an Ionian woman, the correction instead suggests that she was an Athenian, and that either Archermos himself or an Ionian letter cutter in his workshop carved the inscription. $^{70}$

East Greek sculptors and letter cutters clearly did play a major role in introducing Ionic script to Athens, a development that began in the Archaic period but only reached its fruition at the very end of the 5 th century B.c. ${ }^{71}$ Though considerable evidence supports the existence of an East Greek clientele for funerary monuments in Athens in the 6th and 5th centuries B.C., the assumption of an East Greek clientele does not work for the sanctuary dedications of the same period. Instead, an Athenian clientele appears to have exerted some influence over the inscribing practices of non-Athenian letter cutters. If not direct evidence for literacy, the differing patterns of adoption of Ionic letter forms and Ionic spelling conventions, and the evidence for corrections from Ionic into Attic spelling on a small number of Acropolis dedications, at the very least point toward an awareness of script on the part of both the letter cutters who carved inscriptions on stone and their patrons.

68. See $I G \mathrm{I}^{3} 813$; cf. Raubitschek's reading (DAA, p. 288) of the corrected letter as phi $(\Phi)$, not taking the correction into account. 198).

69. $D A A$, pp. 7-8 $\left(I G \mathrm{I}^{3} 683 ; C E G\right.$

70. Cf. Ridgway 1987, pp. 401-402, and Kron 1996, p. 162: "Iphidike was apparently an Ionian woman, but whether a distinguished metic or a rich hetaira cannot be decided."

71. Cf. Aloni's (2000, pp. 91-92) suggestion that the introduction of Ionic letter forms was sponsored by the Peisistratid Hipparchos.
Figure 9. Dedication of Iphidike from the Athenian Acropolis, signed by Archermos of Chios $(D A A 3=$ EM 6241). Detail below shows the letter cutter's correction of an eta into an epsilon in the sculptor's signature. C. M. Keesling 


\section{VASES ON BASES}

The role played by the dedications of Athenian potters and vase painters on the Acropolis as an element of their "biographies" has gone unremarked in many recent critiques of connoisseurship, hand attribution, and the reconstruction of artistic personalities in the study of Athenian vase painting. ${ }^{72}$ We have already seen that the dedicators of $D A A 217$, the Acropolis base for four statuettes described in the first part of this article, may be identified as the red-figure vase painter Onesimos and his son. Several of Raubitschek's approximately 30 identifications of Acropolis dedicators as known potters or painters were speculative, contributing to his larger thesis connecting dedications by craftsmen and other non-aristocrats with the Kleisthenic reforms of 508/7 в.c. ${ }^{73}$ One corollary to Raubitschek's dedications by potters and painters on the Acropolis is the suggestion that some Athenian red-figure vase painters made dedications there late in their lives: this observation originates from attempts to reconcile conflicts between the chronologies of Attic red-figure vase painting and the relative dates for the dedications Raubitschek derived from the letter forms of their inscriptions. ${ }^{74}$

A related claim, stated most clearly in the appendices to $D A A$, has yet to be reexamined: that four of the inscribed bases from the Acropolis supported ceramic, stone, or bronze vases dedicated by Athenian potters or vase painters. ${ }^{75}$ If correctly reconstructed and interpreted, these dedications would represent an unusually direct link between the banausic occupation of the patron and the form of a monumental dedication, and would identify as potters or vase painters four patrons whose occupation would otherwise remain unknown: Aischines ( $D A A 48)$, Smikros ( $D A A 53)$, Kepha[los] (the joint dedicator of $D A A 209$ with Iatrokles), and Xenokles, son of Sosineos (DAA 42).

A black-figure potter named Aischines is known from a "signed stray" found on the Acronolis, and his attributed work was dated by Beazley to the last decade of the 6th century B.c. Raubitschek assigned the same date to the letter forms of the inscribed column $D A A 48\left(I G \mathrm{I}^{3} 631\right)$ dedicated by Aischines. ${ }^{76} D A A 53$ is the inscribed round capital from a lost votive column dedicated to Athena by Smikros and his sons ( $\mu \nu \tilde{\eta} \mu \alpha[\varepsilon \tilde{\rho} \rho \gamma \omega] \nu \theta \alpha \lambda \lambda \delta \dot{\delta} \tau \omega \nu$, a "memorial of thriving works (business)." The vase painter Smikros is a red-figure Pioneer whose work Beazley dated to

72. See, e.g., Whitley 1997 (with a response by Oakley [1998]) and Neer 1997, pp. 21-26. Cf. Vickers and Gill (1994, pp. 93-95), who reject the customary claim that potters and vase painters dedicated monumental votive offerings on the Acropolis as being a symptom of the modern scholarly overvaluation of Athenian painted pottery.

73. See $D A A$, p. 465: "It is notewor- thy that all these dedications are later than 525 в.c., and most of them can be dated after 510 B.c. It is, therefore, safe to assume that the Athenian banausoi, who became wealthy in the course of the second half of the sixth century, gained social standing as well when the democracy was established."

74. See Keesling 2003, pp. 71-74.

75. DAA, p. 465: "Four pedestals (Nos. 42, 48, 53, 209) have circular cut- tings on top in which may have fitted the bases of vases made of clay, stone, or bronze; the names of the dedicators are incidentally known as potters or painters: Aischines, Kephalos, Smikros, Xenokles."

76. For the potter, see $A B V$, p. 351 (Acr. 2692; Graef and Langlotz 19251933, vol. I, pl. 113); Scheibler 1979, p. 12. 
ca. 520-500 в.с. ${ }^{77}$ Though Raubitschek suggested translating $\pi \alpha i \delta \delta \varsigma \varsigma$ here and on another Archaic votive base (DAA 64) as references to pupils or workshop apprentices rather than the dedicator's own children, the formula is well enough attested elsewhere-for example, on the Klepsydra base discussed above - to support a familial interpretation not specifically linked to craft workshops or any other business. ${ }^{78}$ Smikros was a descriptive name common in Athens in the 5th century B.c., when it occurs in citizen casualty lists from three different tribes. ${ }^{79}$ A roughly contemporary, Late Archaic dedication on the Acropolis was made by a tanner called Smikros (DAA 58).

For these reasons, Raubitschek's identification of the dedicator Smikros with the known vase painter of the same name is speculative. In truth, the name matches between the dedicators Aischines (DAA 48) and Smikros (DAA 53) and the known potter and painter of the same names constitute the sole evidence for identifying their Acropolis dedications as vases rather than statues: the round, shallow cuttings with level floors on the tops of both bases fit Raubitschek's own criteria for identifying the plinth cuttings of marble korai. The plinth cutting on Smikros's and his sons' dedication (DAA 53) can be compared with extant under-lifesize Acropolis korai with circular or near-circular plinths, such as the Red Shoes kore (Acr. 683). ${ }^{80}$

Raubitschek's third hypothetical vase dedication is a fragmentary rectangular pillar capital (DAA209) inscribed with the partially preserved names of the joint dedicators Iatrokles and Kepha[los]. Here the association with an Athenian potter is extremely tenuous: a 4th-century Athenian envoy to Chalkis named Kephalos had a father called a kerameus by a scholiast to Aristophanes' Ecclesiazusae. ${ }^{81}$ The dedicator's name might in fact be Kepha[lion], more common in 5th-century Athens. Only a small segment of the plinth cutting on the top of the base survives, which can be reconstructed either as the circular cutting for a marble kore statue or as an oval cutting for a kouros. ${ }^{82}$

The final example proposed by Raubitschek, though the most plausible candidate for the type of votive monument he had in mind, may also have nothing to do with Athenian potters or vase painters. The dedication of Xenokles, son of Sosineos (DAA 42; Acr. 6960), is a small, unfluted

77. $A R V^{2}$, pp. $20-21,1619-1620$; Paralipomena, pp. 322-323; Addenda ${ }^{2}$, p. 154; Boardman 1975, pp. 29-30; Neer 2002, pp. 87-89, 133-134. For a signature of Smikros from the Acropolis, see Graef and Langlotz 19251933, vol. II, p. 238.

78. Examples: Lazzarini 1976, nos. 686 (Delos), 800 (Delphi); Löhr 2000, nos. 19, 27, 64, 70, 81 (Agora relief dedicated by a cobbler and his children), 123, 158, 175. Dedications by unnamed paides who give their father's name in the genitive are slightly more common (Löhr 2000, nos. 1, 4, 5,
$7,11,12,14,15,66,71,76,78,94$, 124, 171).

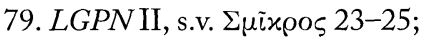
$I G \mathrm{I}^{3} 1186$, line 83 (Aiantis, ca. 411 B.C.); $I G \mathrm{I}^{3} 1184$, line 5 (Akamantis, 423 в.с.); $I G \mathrm{I}^{3} 1147$, line 181 (ML 33; Erechtheis, 459 в.c.).

80. Red Shoes kore: Langlotz 1939, pp. 52-53, no. 9. The diameter of the plinth cutting on $D A A 53$ is $0.225 \mathrm{~m}$; the diameter of the round plinth for the Red Shoes kore is $0.18-0.19 \mathrm{~m}$. The Red Shoes kore originally stood on the right-hand side of a preserved rectangular pillar base ( $D A A 292)$, with an even smaller kore statue on the lefthand side (Raubitschek 1939-1940, pp. 24-25, fig. 15). The diameter of the plinth cutting for the Red Shoes kore is $0.20 \mathrm{~m}$, and that of the circular cutting for the smaller kore is $0.12 \mathrm{~m}$. In his initial publication of $D A A 48$ (Raubitschek 1939-1940, p. 27, figs. 22, 23), Raubitschek had suggested that the circular kore plinth Acr. 456 (diameter $0.175 \mathrm{~m}$ ) might fit in the larger cutting. 81. DAA, pp. 238-239; cf. LGPN II,

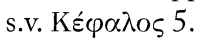

82. Cf. Kissas 2000, pp. 112-113, no. B39. 
Figure 10. Archaic column base from the Athenian Acropolis, dedicated by Xenokles, son of Sosineos $(D A A 42=$ Acr. 6960). Photo C. M. Keesling
83. $D A A$, pp. 45-46; $I G \mathrm{I}^{3} 690$

(ca. $500-480$ в.с.?); Kissas 2000 , p. 232, no. B184.

84. The foot diameters of the preserved bronze hydrias of the Archaic and Classical periods collected by Erika Diehl range from 0.135 to 0.158 m (Diehl 1964, nos. B11, B12, B36, B54, B128, B131, B138, B210). The foot diameters of Archaic bronze hydrias found at Olympia range between 0.14 and $0.16 \mathrm{~m}$ (Gauer 1991,

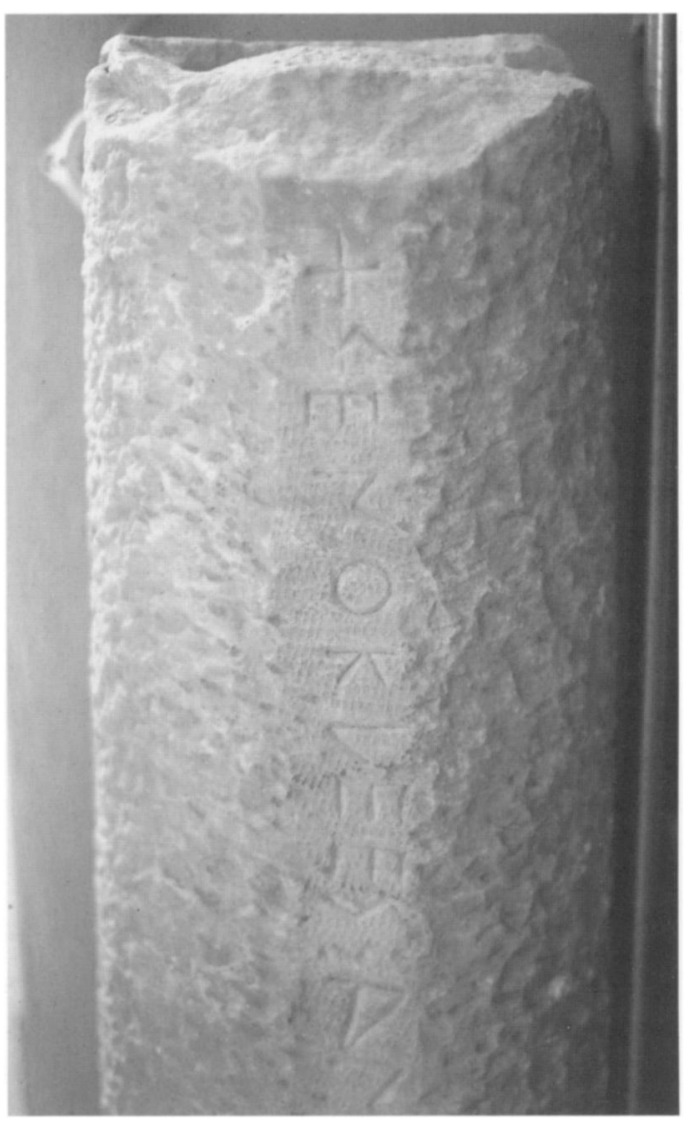

marble column with a circular cutting on top (Fig. 10) ${ }^{83}$ The floor of the cutting is convex, and the holes around the edges may have been designed to receive either metal nails or some of the lead used to attach the lost offering to the cutting. The convex profile of the cutting suggests that it might have held a bronze vessel with a convex foot, and the dimensions $\left(0.15 \mathrm{~m}\right.$ in diameter) are consistent with those of extant bronze hydrias. ${ }^{84}$ Though the name of the dedicator, Xenokles, matches that of a potter of black-figure Little Master cups dated to ca. 525 в.c., the name was common; his father's name Sosineos, on the other hand, was not. ${ }^{85}$ D'Onofrio has pointed out that an individual named Sosineos was commemorated by a funerary monument of ca. $575-550$ B.c. in the Kerameikos, and in this

pp. 108-110, nos. 263-265, and fig. 28); the profiles of several examples would fit the convex shape of the cutting on $D A A 42$. For a bronze hydria from Aigina (ca. 480-460 B.c., foot diameter $0.133 \mathrm{~m}$ ) inscribed as a joint dedication by two brothers, see Löhr 2000, pp. 39-40, no. 42.

85. For the potter Xenokles, see

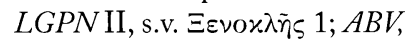
pp. 184-186, 688; Paralipomena, pp. 76-77; Boardman 1974, p. 60.
$I G \mathrm{I}^{3} 690$ gives a date of ca. 500-480 B.c. for the inscribed column $D A A 42$, 25 to 45 years after the floruit of the black-figure potter Xenokles. This is one example of a name match between a known potter or vase painter and a dedicator on the Acropolis contributing to the belief that potters made their dedications late in life (si huius donarii dedicator esset, iam senex fuerit; $I G \mathrm{I}^{3}$ 690). 
case I am inclined to agree that the dedicator Xenokles Sosineou was related to this Sosineos, and that there is little justification in identifying him with the black-figure potter Xenokles. ${ }^{86}$

The dedication of a bronze hydria attached to an inscribed column might be either agonistic or sacrificial in its significance. Though bronze lebetes and tripods are normally considered the prize vessels par excellence in Greek athletics, a bronze hydria worth 30 drachmas was awarded as a prize in the Panathenaic torch race as early as the third quarter of the 5th century B.c. ${ }^{87}$ Beginning in the 5 th century, bronze hydrias were given as prizes alongside lebetes in the games commemorating the war dead at Marathon. ${ }^{88}$ Hydrias, however, were also used to carry water for sacrifices, and it is possible that Xenokles' dedication of a bronze hydria was meant to allude to sacrifice in much the same way as statues and statuettes representing sacrificial animals, a familiar type of votive offering in the Archaic and Classical periods. ${ }^{89}$ Similarly, dedications of bronze bowls and tripods in Greek sanctuaries were multivalent, in some cases commemorating agonistic victory and in others associated with sacrifice. ${ }^{90}$ In either case, dedications of bronze vases that were "monumentalized" through their attachment to inscribed stone bases such as that of Xenokles probably had no connection with the potters and vase painters of the Kerameikos as a clientele. ${ }^{91}$ Vessels of sacrificial significance attached to bases may well have been a common dedication type in Greek sanctuaries in the Archaic and Classical periods, and given the widespread disappearance of bronzes of all types we should not be surprised if only their bases survive. ${ }^{92}$

There is an important Late Classical postscript to Raubitschek's hypothesis that Athenian potters and painters of the Late Archaic period dedicated vases attached to inscribed stone bases. In 1934, Meritt published a Pentelic marble fragment found in Late Roman fill in front of the

86. D’Onofrio 1998, p. 113

87. The hydria is listed as a prize in the Panathenaic prize list of ca. 380 в.с. ( $I G \mathrm{II}^{2} 2311$, line 89); for a revised text of the inscription and further references, see Shear 2003. A hydria appears already in a red-figure scene of a torch race dated to ca. 430-420 в.с. (Neils 1992, pp. 178-179; Shear 2001, pp. 335-339). The 30-drachma price of the hydria awarded at the Panathenaia suggests that it was made of bronze (Diehl 1964, p. 195). Comparable ceramic vessels of the same period in Athens were considerably cheaper (Johnston 1991, pp. 227-228; Sparkes 1996, pp. 140-145; Neer 2002, pp. 211-212).

88. For a bronze hydria inscribed as a prize from Marathon found near Thessaloniki, see $I G \mathrm{I}^{3}$ 525; Vanderpool 1969. For other inscribed bronze prize hydrias, see Kephalidou 1996, pp. 114-119, nos. 15-17, 20, 21g, 22a, 22b, 23, 24.

89 . For the use of hydrias in sacrifice, see Diehl 1964, pp. 171-209; Van Straten 1995, pp. 41-42, fig. 41, pp. 49-50, fig. 53 (late-5th-century sacrifice scenes on Athenian red-figure pottery).

90. Tripods as agonistic and choregic dedications: Scheibler 1988; Amandry 1976, pp. 15-19; Podlecki 1981. Sacrificial associations: Herrmann 1979, pp. 6-7. Kron (1998) makes a similar point about dedications of metal sickles in Greek sanctuaries.

91. The Late Archaic Potter Relief in the Acropolis Museum, normally interpreted as the dedication of a potter of red-figure "Acrocups" (Beazley 1946, pp. 22-23; cf. Raubitschek 1942), had a central acroterion (now in the Epigraphical Museum [EM 6520]) with a circular, concave cutting that probably supported a bronze footed vase, either a hydria or a smaller pouring vessel judging by the diameter of the cutting $(0.13 \mathrm{~m})$. An uninscribed round capital from the Acropolis published by Kissas (2000, pp. 199-201, no. B156) has a circular cutting with a convex floor (diameter $0.16 \mathrm{~m}$ ), which may, like $D A A 42$, have supported a bronze hydria.

92. On the Acropolis, dedications of bronze tripods began in the Geometric period (Touloupa 1991). Uninscribed bases for bronze tripods or lebetes (published in Stevens 1951; and Kissas 2000, pp. 211-213, no. B166, pp. 229230 , no. $\mathrm{B} 180)$ and several inscribed bases (DAA 317-322, 372) survive from the Archaic period. There is also a series of more than 50 fragments of inscribed Archaic bronze lebetes $\left(I G \mathrm{I}^{3}\right.$ 550-583, fr. ff). 
Metroön on the west side of the Athenian Agora that he identified only as a "circular plinth." The vertical surface of the plinth features a complete, two-word dedicatory inscription ( $\left.I G \mathrm{II}^{2} 4921 \mathrm{a}\right)$ in lettering of the 4th cen-

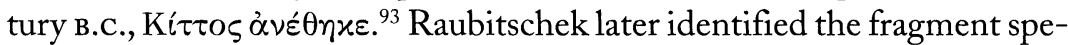
cifically as "the lower part of a pedestal for a marble basin" (perirrhanterion), and compared it to a series of Late Archaic marble perirrhanteria with inscribed rims dedicated on the Acropolis by Onesimos, son of Smikythos, the dedicator of $D A A 217$ discussed in the first part of this article. ${ }^{94} \mathrm{He}$ associated Kittos with the 4th-century ceramic workshop of Bakchios and Kittos, attested by a series of signatures on Panathenaic prize amphoras dated by their archon years to the second quarter of the 4th century. ${ }^{95}$

A potter named Bakchios-but not necessarily the same Bakchios whose signature appears on a Panathenaic amphora of 375/4 B.c.- -was buried in the Kerameikos with an inscribed funerary monument of the second half of the 4th century в.c. ( $\left.I G \mathrm{II}^{2} 6320\right)$. The inscription refers specifically to the craft of the deceased, claiming that he won stephanoi "in all the contests this city established." 96 The "contests" in question have been interpreted as the competition held every four years to award the contract to produce the Panathenaic prize amphoras for the athletic contests of the Greater Panathenaia: P. Valavanis has argued that the workshop of Bakchios and Kittos may in fact have produced all of the amphoras awarded in the second and third quarters of the 4th century. ${ }^{97}$ Finally, between ca. 330 and 320, the city of Ephesos awarded citizenship to two Athenian potters named Bakchios and Kittos in thanks for providing the

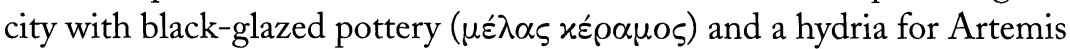
(I.Eph. 1420). The fragmentary marble perirrhanterion from the Agora dedicated to an unnamed deity by Kittos thus appeared to provide 4thcentury evidence to support Raubitschek's link between monumental dedications and Athenian potters.

The name Kittos is attested in other contexts in 4th-century Athens, once again raising the problem of name duplication: the Kittos named on the Agora fragment might not be a member of the known family of potters. ${ }^{98}$ The more serious problem in this case, though, is Raubitschek's identification of the fragment as the base for a perirrhanterion. Meritt's photograph shows the inscription on the vertical face of the round plinth,

93. Meritt 1934 , p. 66 , no. 59 (Agora I 28).

94. Raubitschek 1942, pp. 309-310. There are eight perirrhanteria $(D A A$ 349-353, 357, and 358 [ = IG $\mathrm{I}^{3}$ 926932], and $I G I^{3}$ 933) in which Onesimos's name is preserved or has been conjecturally restored.

95. For the workshop of Bakchios and Kittos, see $A B V$, p. 413; Addend ${ }^{2}$, pp. 107-108; Beazley 1943, pp. 455457; Frel 1973, pp. 21-22, fig. 19 (signature of Bakchios on a fragmentary amphora dated to $375 / 4$ в.c.); Vickers and Gill 1994, pp. 96-97;
Bentz 1998, pp. 27-31.

96. Wilhelm 1909, pp. 40-42, fig. 18; 1921, pp. 39-44; CEG 2567 (EM 161). The name, patronymic, and demotic (Kerameus) of Bakchios are inscribed in large letters on a short cylinder carved in one piece with the rectangular base where the epigram is inscribed. The circular cutting on the top surface of the cylinder $(0.20 \mathrm{~m}$ in diameter and $0.05 \mathrm{~m}$ deep) probably supported a marble funerary vase of one of the types common in Attic cemeteries before the sumptuary law of Demetrios of Phaleron in the last quarter of the 4th century B.c. (discussed by Engels 1998, pp. 121-154). The earliest known examples of stone vases of any kind from Athens date to the end of the 5th century в.c. (loutrophoroi: Kokula 1984, pp. 15-20, 31-34; Dehl 1981; lekythoi: Prukakis-

Christodulopulos 1970, pp. 62, 65).

97. Valavanis 1997, pp. 90-91.

98. Instances of the name ( $L G P N$ II,

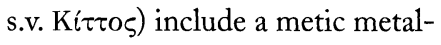
worker listed as dedicator of a silver phiale in an inscribed inventory of ca. 330 в.c. $\left(I G \mathrm{II}^{2} 1554\right.$, line 10), discussed by Hurwit (1999, pp. 61-62). 


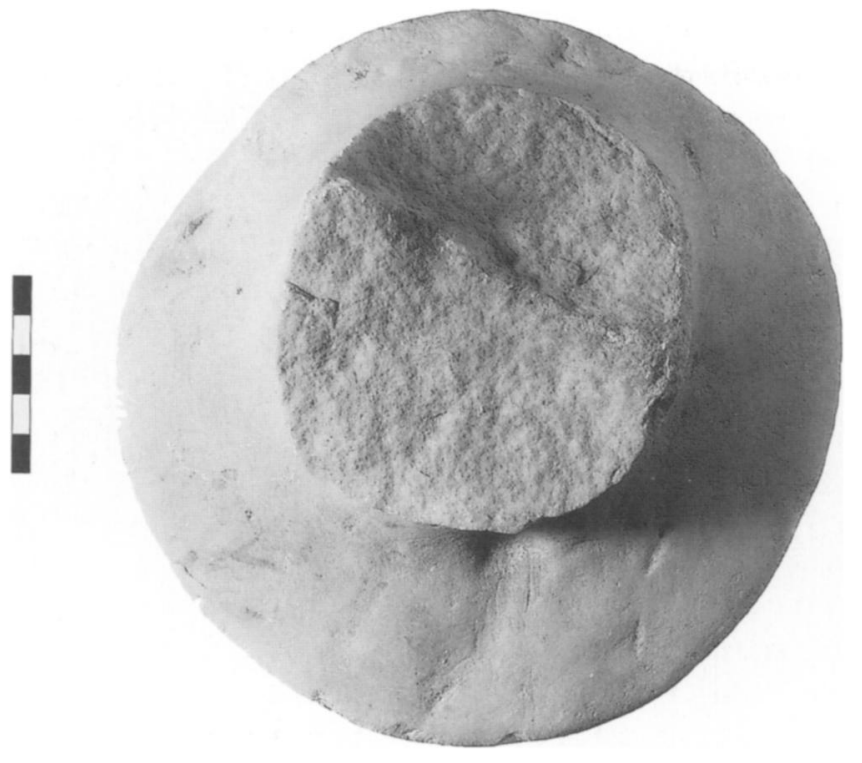

but a view of the fragment from above (Fig. 11) reveals that the object dedicated by Kittos was not a perirrhanterion or even a marble vase, but rather a slightly under-lifesize human head: the neck rises asymmetrically from the plinth, and shows a clear depression between the carotid arteries in the neck, above the inscribed plinth. The plinth is higher on the left $(0.07 \mathrm{~m})$ than on the right $(0.06 \mathrm{~m})$, suggesting the beginnings of uneven shoulders. The neck breaks off well below the chin, and there are no traces of hair or other features that would reveal the subject represented by the lost head. ${ }^{99}$

Both the function and setting of the marble head dedicated by Kittos pose problems. Though it is conceivable that the head was originally intended to be attached either to a separately carved marble body or to a wooden one using the acrolithic technique, preserved marble heads of both types tend to have bottom tenons much thicker than the short $(0.05 \mathrm{~m}$ high) plinth on which the Kittos head stood. Unlike such marble heads, the head dedicated by Kittos was designed to stand upright on its inscribed plinth. ${ }^{100}$ The plinth might have been placed in a shallow cutting (no more than $0.02 \mathrm{~m}$ deep) on the top of a base without obscuring the dedicatory inscription. The closest parallels for such a display, themselves unique, are the marble heads of a series of six goddesses attached to an Early Hellenistic altar at Pherai in Thessaly, published by Stephen Miller. ${ }^{101}$ Here the heads were placed in plinth cuttings and secured in place with molten lead, the normal attachment technique for the plinths of marble statues, and accompanied by name labels inscribed on the altar itself rather than on each head's plinth.

We might conjecture instead that the marble head dedicated by Kittos was an anatomical votive dedicated to Asklepios, whose sanctuary in the city of Athens was founded on the South Slope of the Acropolis in 420/19 B.c. Though heads were less common than other body parts as anatomical votives dedicated in Asklepieia, several 4th-century freestanding, lifesize terracotta heads were found in the Asklepieion at Corinth. ${ }^{102}$ Among the
Figure 11. Inscribed 4th-century в.c. plinth for marble head from the Athenian Agora, dedicated by Kittos (Agora I 28). View from above showing remains of the neck. Courtesy American School of Classical Studies at Athens, Agora Excavations
99. The diameter of the neck at the break is $0.108 \mathrm{~m}$. The vertical edge of the plinth is distinctly marked only at the front; at the back, it merges into the back of the neck.

100. For the acrolithic technique, see Häger-Weigel 1997; Lundgreen 1997, pp. 11-13. For marble statues with separately inserted heads, see Claridge 1990, pp. 142-144; Hermary 1998.

101. Miller 1974.

102. See Corinth XIV, pp. 119-120, nos. 2-6; no. 2 (pl. 30) is a 4th-century female head $0.291 \mathrm{~m}$ tall, with the base of the neck "extended in a flange to serve as a resting surface" (p. 119), much like the plinth of the head dedicated by Kittos. 
lost votive offerings listed in the inscribed inventories of the Athenian Asklepieion are four heads. Many of the anatomical votives dedicated in Asklepios sanctuaries in Athens and Attica, unlike those from Corinth, were made of marble and inscribed. ${ }^{103}$ The terracotta heads from Corinth give no indication of the dedicators' illnesses, and thus the head dedicated by Kittos might not have featured any special characteristics identifying it as an anatomical votive other than its unusual format. The proposed reidentification of Kittos's dedication as a marble head dedicated to Asklepios, like the reinterpretation of Archaic dedications of metal vessels on bases on the Acropolis, effectively removes the connection Raubitschek hypothesized between the dedication type and the dedicator's occupation as a potter.

\section{CONCLUSION}

Though private patrons clearly exerted some influence upon the format of dedications and the texts of their inscriptions, their role in Archaic and Classical Athens defies casual generalizations. Some patrons chose to combine their offerings on the same base with separate inscriptions, a form of sculptural display difficult to reconcile with aesthetic principles, but justified within the context of votive religion. On a statue base now built into the Klepsydra springhouse on the Acropolis North Slope (Agora I 5517) and an Acropolis base dedicated by Onesimos and Theodoros (DAA217), statuettes that may even have included multiples of the same sculptural type were lined up in a row; on another statue base from the Acropolis (DAA210), two marble quadrupeds of drastically different sizes stood perpendicular to one another.

The effect private patrons had upon the content and style of inscriptions has always been particularly difficult to determine. Ionic letter forms and spelling conventions were common on Archaic dedications from Athens. The use of one feature of Ionic spelling, the letter eta $(\mathrm{H})$, seems to correlate with the work of non-Athenian sculptors and letter cutters, but not with non-Athenian patrons. In general, the clientele for sanctuary dedications in Archaic Athens seems to have been distinct from the clientele for funerary monuments, which included more non-Athenians of Ionian origin. Standard dedication types and occasions for dedication seem not to have varied according to the occupation or social status of the dedicator. In this respect, the so-called Potter Relief from the Acropolis, which

103. See Forsén 1996, pp. 114-120; Van Straten 1981, pp. 108-109. For a 4th-century votive relief representing a face from the Athenian Asklepieion, see $I G \mathrm{II}^{2}$ 4372; Salta 2003. depicts a potter or metalworker holding examples of his wares, was the exception, not the rule. Several other possible dedications by Athenian potters and vase painters, including one made by Kittos in the 4th century, have been either misidentified as such or reconstructed erroneously as metal or stone vases. 


\section{REFERENCES}

Addenda ${ }^{2}=$ T. H. Carpenter, Beazley Addenda: Additional References to $A B V, A R V^{2}$, and Paralipomena, 2nd ed., Oxford 1989.

Agora XXV = M. Lang, Ostraka (Agora XXV), Princeton 1990.

Aloni, A. 2000. "Anacreonte a Atene: Datazione e significato di alcune iscrizioni tiranniche," ZPE 130, pp. 81-94.

Amandry, P. 1976. “Trépieds d'Athènes: I. Dionysies," BCH 100, pp. 15-93.

Andreiomenou, A. K. 1999. "H $\varepsilon \xi$

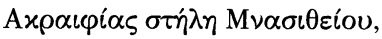

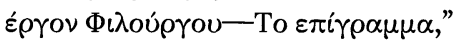
ArchEph 1999, pp. 81-127.

. 2000. "Zur Werkstatt des

Endoios und Philourgos," $A M 115$, pp. 83-113.

Angiolillo, S. 1997. Arte e cultura nell' Atene di Pisistrato e dei Pisistratidi:

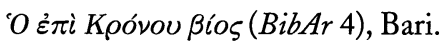

Beazley, J. D. 1943. "Panathenaica," AJA 47, pp. 441-465.

- 1946. Potter and Painter in Ancient Athens, London.

Bentz, M. 1998. Panathenäische Preisamphoren: Eine athenische Vasengattung und ibre Funktion vom 6.-4. Jabrbundert v. Chr. (AntK-BH 18), Basel.

Blok, J. H. 2000. “Phye's Procession: Culture, Politics, and Peisistratid Rule," in Sancisi-Weerdenburg 2000, pp. 17-48.

Boardman, J. 1972. "Herakles, Peisistratos, and Sons," RA1972, pp. 5772 .

- 1974. Athenian Black Figure Vases, London.

-1975. Athenian Red Figure Vases: The Archaic Period. A Handbook, London.

Boedeker, D., and K. A. Raaflaub, eds. 1998. Democracy, Empire, and the Arts in Fifth-Century Athens, Cambridge, Mass.

Brenne, S. 2000. "Indices zu KalosNamen," Tyche 15, pp. 31-53.

Broneer, O. 1938. "Excavations on the North Slope of the Acropolis, 1937," Hesperia 7, pp. 161-263.

$C E G=\mathrm{P}$. A. Hansen, Carmina epigraphica graeca saeculorum VIIIVa. Chr. n., Berlin 1983.
$C E G 2$ = P. A. Hansen, Carmina epigraphica graeca, saeculi IV a. Chr. $n$. (CEG 2), Berlin 1989.

Chambers, M. H., R. Gallucci, and P. Spanos. 1990. “Athens' Alliance with Egesta in the Year of Antiphon," ZPE 83, pp. 38-63.

Clairmont, C. W. 1983. Patrios Nomos: Public Burial in Athens during the Fifth and Fourth Centuries B.C.: The Archaeological, EpigraphicLiterary, and Historical Evidence (BAR-IS 161), Oxford.

Claridge, A. 1990. "Ancient Techniques of Making Joins in Marble Statuary," in Marble: Art Historical and Scientific Perspectives on Ancient Sculpture, ed. M. True and J. Podany, Malibu, pp. 135-162.

Cook, R. M. 1997. Greek Painted Pottery, 3rd ed., London.

Corinth XIV = C. Roebuck, The Asklepieion and Lerna (Corinth XIV), Princeton 1951.

Coulson, W. D. E., et al., eds. 1994. The Archaeology of Athens and Attica under the Democracy. Proceedings of an International Conference Celebrating 2,500 Years since the Birth of Democracy in Greece, Held at the American School of Classical Studies at Athens, December 4-6, 1992 (Oxbow Monograph 37), Oxford.

Cox, C. A. 1998. Household Interests: Property, Marriage Strategies, and Family Dynamics in Ancient Athens, Princeton.

$D A A=$ A. E. Raubitschek, Dedications from the Athenian Akropolis: A Catalogue of the Inscriptions of the Sixth and Fifth Centuries B.C., Cambridge, Mass., 1949.

Dehl, C. 1981. "Eine Gruppe früher Lutrophorenstelen aus dem Kerameikos," $A M 96$, pp. 163-178.

Diehl, E. 1964. Die Hydria: Formgeschichte und Verwendung im Kult des Altertums, Mainz.

D’Onofrio, A. M. 1982. “Korai e kouroi funerari attici," AnnArchStorAnt 4, pp. 135-170.

. 1988. "Aspetti e problemi del monumento funerario attico arcaico," AnnArchStorAnt 10, pp. 83-96. 
1998. “Oikoi, généalogies, et monuments: Réflexions sur le système de dédicaces dans l'Attique archaïque," Ktema 23, pp. 103-123.

Dow, S. 1975. "Introduction: The Study of Lettering," in Tracy 1975, pp. xiii-xxiii.

Eaverly, M. A. 1995. Archaic Greek Equestrian Sculpture, Ann Arbor.

Engels, J. 1998. Funerum sepulcrorumque magnificentia: Begräbnis- und Grabluxusgesetze in der griechisch-römischen Welt, mit einigen Ausblicken auf Einschränkungen des funeralen und sepulkralen Luxus im Mittelalter und in der Neuzeit (Hermes Einzelschriften 78), Stuttgart.

Felsch, R. C. S. 1991. "Tempel und Altäre im Heiligtum der Artemis Elaphebolos von Hyampolis bei Kalapodi," in L'espace sacrificiel dans les civilisations méditerranéennes de l'antiquité. Actes du colloque tenu à la Maison d'Orient, Lyon, 4-5 juin 1988 (Publications de la Bibliothèque Salomon Reinach 5), ed. R. Etienne and M.-T. Le Dinahet, Paris, pp. 85-91.

Forsén, B. 1996. Griechische GliederWeibungen: Eine Untersuchung zu ibrer Typologie und ibrer religionsund sozialgeschichtlichen Bedeutung (Papers and Monographs of the Finnish Institute at Athens 4), Helsinki.

Foxhall, L. 1989. "Household, Gender, and Property in Classical Athens," CQ 39, pp. 22-44.

Frel, J. 1973. Panathenaic Prize Amphoras (Kerameikos 2), Athens.

Friis Johansen, K. 1951. The Attic GraveReliefs of the Classical Period: An Essay in Interpretation, Copenhagen.

Garland, R. 1989. “The Well-Ordered Corpse: An Investigation into the Motives behind Greek Funerary Legislation," BICS 36, pp. 1-15.

Gauer, W. 1991. Die Bronzegefässe von Olympia, mit Ausnabme der geometrischen Dreifüsse und der Kessel des orientalisierenden Stils 1: Kessel und Becken mit Untersätzen, Teller, Kratere, Hydrien, Eimer, Situlen und Cisten, Schöpfbumpen und verscheidenes Gerät (OlForsch XX), Berlin.

Gill, D. 1991. Greek Cult Tables

(Harvard Dissertations in Classics), New York.
Glowacki, K. T. 1998. "The Acropolis of Athens before 566 в.c.," in $\Sigma \tau \varepsilon ́ \varphi \alpha \nu o \varsigma:$ Studies in Honor of Brunilde Sismondo Ridgway (University Museum Monograph 100), ed. K. J. Hartswick and M. C. Sturgeon, Philadelphia, pp. 79-88.

Graef, B., and E. Langlotz. 1925-1933. Die antike Vasen von der Akropolis zu Athen, 2 vols., Berlin.

Hadzisteliou Price, T. 1971. "Double and Multiple Representations in Greek Art and Religious Thought," JHS 91, pp. 48-69.

Häger-Weigel, E. 1997. Griechische Akrolith-Statuen des 5. und 4. Jbs. v. Chr. (Wissenschaftliche Schriftenreihe Archäologie 4), Berlin.

Harrison, E. B. 1956. "Archaic Gravestones from the Athenian Agora," Hesperia 25, pp. 25-45.

Havelock, E. A. 1982. The Literate Revolution in Greece and Its Cultural Consequences, Princeton.

Hedrick, C. W. 1988. "The Temple and Cult of Apollo Patroos in Athens," AJA 92, pp. 185-210.

Hermary, A. 1998. "Les têtes rapportées dans la sculpture grecque archaïque," BCH 122, pp. 53-74.

Herrmann, H.-V. 1979. Die Kessel der orientalisierenden Zeit 2: Kesselprotomen und Stabdreifüsse (OlForsch XI), Berlin.

Holloway, R. R. 1992."Why Korai?" OJA 11, pp. 267-274.

Hurwit, J. M. 1999. The Athenian Acropolis: History, Mythology, and Archaeology from the Neolithic Era to the Present, Cambridge.

I.Eph. = H. Wankel et al., eds., Die Inschriften von Ephesos I-VIII (IGSK 11-17), Bonn 1979-1984.

Immerwahr, H. R. 1990. Attic Script: A Survey (Oxford Monographs on Classical Archaeology), Oxford.

Ioakimidou, C. 1997. Die Statuenreiben griechischer Poleis und Bünde aus spätarchaischer und klassischer Zeit (Quellen und Forschungen zur antiken Welt 23), Munich.

Jacquemin, A. 1999. Offrandes monumentales à Delphes (BÉFAR 304), Athens.

Jeffery, L. H. 1962. “The Inscribed Gravestones of Archaic Attica," BSA 57, pp. 115-153.

Johnston, A. 1991. "Greek Vases in the Marketplace," in Looking at Greek Vases, ed. T. Rasmussen and N. Spivey, Cambridge, pp. 203-232.

Kabus-Preisshofen, R. 1975. "Statuettengruppe aus dem Demeterheiligtum bei Kyparissi auf Kos," AntP 15, pp. 31-64.

Kaltsas, N. 2002. "Die Kore und der Kuros aus Myrrhinous," AntP 28, pp. 7-40.

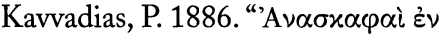

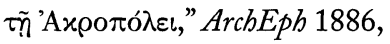
cols. 73-82.

Keesling, C. M. 1999. "Endoios's Painting from the Themistoklean Wall: A Reconstruction," Hesperia 68, pp. 509-548.

-2003. The Votive Statues of the Athenian Acropolis, Cambridge.

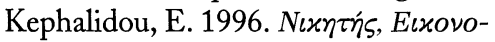

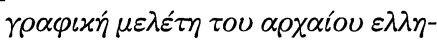
vเxoú $\alpha \theta \lambda \eta \tau \iota \sigma \mu o u ́$, Thessaloniki.

Kissas, K. 2000. Die attischen Statuenund Stelenbasen archaischer Zeit, Bonn.

Knigge, U. 1969. “Zum Kuros vom Piräischen Tor," $A M$ 84, pp. 76-86.

-1991. The Athenian Kerameikos: History, Monuments, Excavations, trans. J. Binder, Athens.

Kokula, G. 1984. Marmorlutrophoren (AM-BH 10), Berlin.

Korres, M. 1997. “An Early Attic Ionic Capital and the Kekropion on the Athenian Acropolis," in Greek Offerings: Essays on Greek Art in Honour of John Boardman (Oxbow Monograph 89), ed. O. Palagia, Oxford, pp. 95-107.

Kreeb, M. 1986. "А $\nu \alpha \theta \eta \mu \alpha \tau \iota x \dot{~} \varepsilon \pi l-$

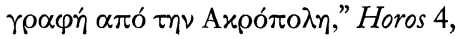
pp. 25-29.

Kron, U. 1996. "Priesthoods, Dedications, and Euergetism: What Part Did Religion Play in the Political and Social Status of Greek Women?" in Religion and Power in the Ancient Greek World. Proceedings of the Uppsala Symposium 1993 (Acta Universitatis Upsaliensis, Boreas 24), ed. P. Hellström and B. Alroth, Uppsala, pp. 139-182.

_. 1998. "Sickles in Greek Sanctuaries: Votives and Cultic Instruments," in Ancient Greek Cult Practice from the Archaeological Evidence. Proceedings of the Fourth International Seminar on Ancient Greek 
Cult, Organized by the Swedish Institute at Athens, 22-24 October 1993 (SkrAtb 15), ed. R. Hägg, Stockholm, pp. 187-215.

Lang, M. 1982. "Writing and Spelling on Ostraka," in Studies in Attic Epigraphy, History, and Topography Presented to Eugene Vanderpool (Hesperia Suppl. 19), Princeton, pp. 75-87.

Langlotz, E. 1939. "Die Koren," in Die archaischen Marmorbildwerke der Akropolis, ed. H. Schrader, Frankfurt, pp. 3-184.

Lazzarini, M. L. 1976. Le formule delle dediche votive nella Grecia arcaica (MemLinc ser. 8, no. 19.2), Rome.

$L G P N \mathrm{II}=\mathrm{M}$. J. Osborne and S. G. Byrne, eds. A Lexicon of Greek Personal Names II: Attica, Oxford 1994.

Lindenlauf, A. 1997. "Der Perserschutt der Athener Akropolis," in Kult und Kultbauten auf der Akropolis. Internationales Symposion von 7. bis 9. Juli in Berlin (Schriften des Seminars für Klassische Archäologie der Freien Universität Berlin), ed. W. Hoepfner, Berlin, pp. 46-115.

Littman, R. J. 1979. “Kinship in Athens," AncSoc 10, pp. 5-31.

Löhr, C. 2000. Griechische Familienweibungen: Untersuchungen einer Repräsentationsform von ibren Anfängen bis zum Ende des 4. Jbs. v. Chr. (Internationale Archäologie 54), Rahden, Westphalia.

Lolling, A. 1890. “'Е $\pi \nmid \gamma \rho \alpha \varphi \iota x \alpha \grave{\iota} \alpha \nu \alpha-$

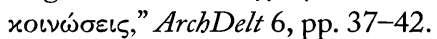

Lundgreen, B. 1997. "The Athena Medici Reconsidered," AnalRom 24, pp. 7-52.

Martin, A. 1990. Rev. of M. Detienne, ed., Les savoirs de l'écriture en Grèce ancienne, in AntCl 59, pp. 457-458.

Marx, P. A. 2001. "Acropolis 625 (Endoios Athena) and the Rediscovery of Its Findspot," Hesperia 70, pp. 221-254.

Mattusch, C. C. 1988. Greek Bronze Statuary: From the Beginnings through the Fifth Century B.C., Ithaca. - 1994. "The Eponymous Heroes: The Idea of Sculptural Groups," in Coulson et al. 1994, pp. 73-81.

McGowan, E. P. 1997. “The Origins of the Athenian Ionic Capital," Hesperia 66, pp. 209-233.
Meiggs, R. 1966. "The Dating of Fifth-Century Attic Inscriptions," JHS 86, pp. 86-98.

Meritt, B. D. 1934. "The American Excavations in the Athenian Agora, Third Report: The Inscriptions," Hesperia 3, pp. 1-128.

Meritt, B. D., M. L. Lethen, and G. Stamires. 1957. "Greek Inscriptions," Hesperia 26, pp. 24-97.

Meyer, E. A. 1993. "Epitaphs and Citizenship in Classical Athens," JHS 113, pp. 99-121.

Mikalson, J. D. 1984. "Religion and the Plague in Athens, 431-423 в.с.," in Rigsby 1984, pp. 217-225.

Miller, S. G. 1974. "The Altar of the Six Goddesses in Thessalian Pherai," CSCA 7, pp. 231-256.

$\mathrm{ML}=\mathrm{R}$. Meiggs and D. M. Lewis, eds. A Selection of Greek Historical Inscriptions to the End of the Fifth Century B.C., rev. ed., Oxford 1988.

Morris, I. 1992. Death-Ritual and Social Structure in Classical Antiquity (Key Themes in Ancient History), Cambridge.

- 1994. "Everyman's Grave," in Athenian Identity and Civic Ideology, ed. A. L. Boegehold and A. C. Scafuro, Baltimore, pp. 67-101.

Morris, I., and K. Raaflaub, eds. 1998. Democracy 2500? Questions and Challenges (Colloquia and Conference Papers 2), Dubuque.

Morris, S. 1992. Daidalos and the Origins of Greek Art, Princeton.

Mylonas, K. D. 1891. “'A $\nu \alpha \theta \eta \mu \alpha \tau \iota x o ̀ \nu$

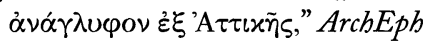
1891, cols. 1-10.

Neer, R. T. 1997. "Beazley and the Language of Connoisseurship," Hephaistos 15, pp. 7-30.

-2002. Style and Politics in Athenian Vase-Painting: The Craft of Democracy, ca. 530-460 B.C.E. (Cambridge Studies in Classical Art and Iconography), Cambridge.

Neils, J., ed. 1992. Goddess and Polis: The Panathenaic Festival in Ancient Athens (Exhibition catalogue, Hood Museum of Art, Dartmouth College), Princeton.

Niemeier, W.-D. 2002. Der Kuros vom Heiligen Tor: Überraschende Neufunde archaischer Skulptur im Kerameikos in Athen (AntW Sonderheft), Mainz. 
Nulton, P. E. 2003. The Sanctuary of Apollo Hypoakraios and Imperial Athens (Archaeologia Transatlantica 21), Providence.

Oakley, J. H. 1998. "Why Study a Greek Vase-Painter? A Response to Whitley's 'Beazley as Theorist,"' Antiquity 72, pp. 209-213.

Parker, R. 1996. Athenian Religion: A History, Oxford.

Parsons, A. W. 1943. "Klepsydra and the Paved Court of the Pythion," Hesperia 12, pp. 191-267.

Phillips, D. J. 1990. “Observations on Some Ostraka from the Athenian Agora," ZPE 83, pp. 123-148.

Podlecki, A. J. 1981. "Some Early Athenian Commemorations of Choral Victories," in Classical Contributions: Studies in Honour of Malcolm Francis McGregor, ed. G. S. Shrimpton and D. J. McCargar, Locust Valley, N.Y., pp. 95-101.

Prukakis-Christodulopulou, A. 1970. “Einige Marmorlekythen," AM 85, pp. 54-99.

Raubitschek, A. E. 1938. "Zur Technik und Form der altattischen Statuenbasen," BLABulg 12, pp. 132-181.

- 1939-1940. "Early Attic Votive Monuments," BSA 40, pp. 1737.

. 1942. "Notes on Attic Prosopography," Hesperia 11, pp. 304313.

Redman, C. L. 1977. "The 'Analytical Individual' and Prehistoric Style Variability," in The Individual in Prehistory: Studies of Variability in Style in Prebistoric Technologies (Studies in Archaeology Series), ed. J. N. Hill and J. Gunn, New York, pp. 41-53.

Richter, G. M. A. 1961. The Archaic Gravestones of Attica, 2nd ed., London.

Ridgway, B. S. 1987. “Ancient Greek Women and Art: The Material Evidence," AJA 91, pp. 399-409.

Rigsby, K. J., ed. 1984. Studies Presented to Sterling Dow on His Eightieth Birthday (GRBM 10), Durham, N.C.

Robertson, M. 1992. The Art of VasePainting in Classical Athens, Cambridge.

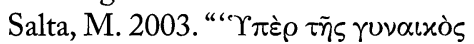

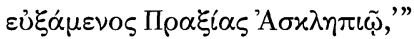

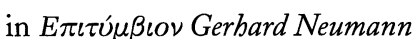

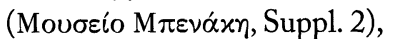
ed. D. Damaskos, Athens, pp. 171182.

Sancisi-Weerdenburg, H., ed. 2000. Peisistratos and the Tyranny: A Reappraisal of the Evidence (Publications of the Netherlands Institute at Athens 3), Amsterdam.

Schanz, H. L. 1980. Greek Sculptural Groups, Archaic and Classical (Outstanding Dissertations in the Fine Arts), New York.

Scheibler, I. 1979. "Griechische Künstlervotive der archaischen Zeit," MüJb 30, pp. 7-30.

- 1988. "Dreifussträger," in Kanon: Festschrift Ernst Berger, zum 60. Geburtstag am 26. Februar 1988 gewidmet (AntK-BH15), ed. M. Schmidt, Basel, pp. 310-316.

Schneider, L. A. 1975. Zur sozialen Bedeutung der archaischen Korenstatuen (HBA 2), Hamburg.

Seaford, R. 1994. Reciprocity and Ritual: Homer and Tragedy in the Developing City-State, Oxford.

Shapiro, H. A. 1989. Art and Cult under the Tyrants in Athens, Mainz.

-1995. Art and Cult under the Tyrants in Atbens, Supplement, Mainz.

- 2001. "Zum Wandel der attischen Gesellschaft nach den Perserkriegen im Spiegel der AkropolisWeihungen," in Gab es das griechische Wunder? Griechenland zwischen dem Ende des 6. und der Mitte des 5. Jahrhunderts v. Chr., ed. D. Papenfuss and V. M. Strocka, Mainz, pp. 91100.

Shear, J. L. 2001. "Polis and Panathenaia: The History and Development of Athena's Festival" (diss. Univ. of Pennsylvania). 2003. "Prizes from Athens: The List of Panathenaic Prizes and the Sacred Oil," ZPE 142, pp. 87108.

Slings, S. R. 2000. "Literature in Athens, 566-510 в.c.," in SancisiWeerdenburg 2000, pp. 57-77.

Sourvinou-Inwood, C. 1995. "Reading" Greek Death: To the End of the Classical Period, Oxford.

Sparkes, B. A. 1996. The Red and the Black: Studies in Greek Pottery, New York.
Stears, K. 2000. “'The Times They Are A'changing': Developments in Fifth-Century Funerary Sculpture," in The Epigraphy of Death: Studies in the History and Society of Greece and Rome, ed. G. J. Oliver, Liverpool, pp. 25-58.

Stevens, G. P. 1951. "The Poros Tripods of the Acropolis of Athens," in Studies Presented to David Moore Robinson on His Seventieth Birthday 1, ed. G. E. Mylonas, St. Louis, pp. 331-335.

Stupperich, R. 1994. “The Iconography of Athenian State Burials in the Classical Period," in Coulson et al. 1994, pp. 93-103.

Threatte, L. L. 1980. The Grammar of Attic Inscriptions 1: Phonology, Berlin.

- 1996. The Grammar of Attic Inscriptions 2: Morphology, Berlin.

Tölle-Kastenbein, R. 1992. "Die Athener Akropolis-Koren: Ort, Anlässe, und Zeiten ihrer Aufstellung," AntW23, pp. 133-148.

Touloupa, E. 1991. "Early Bronze Sheets with Figured Scenes from the Acropolis," in New Perspectives in Early Greek Art (Studies in the History of Art 32, Symposium Papers 16), ed. D. Buitron-Oliver, Hanover, N.H., pp. 236-244.

Tracy, S. V. 1975. The Lettering of an Athenian Mason (Hesperia Suppl. 15), Princeton. . 1984. "Hands in Fifth-Century в.c. Attic Inscriptions," in Rigsby 1984, pp. 277-282.

- 1990. Attic Letter-Cutters of 229 to 86 B.C. (Hellenistic Culture and Society 6), Berkeley.

Travlos, J. 1971. Pictorial Dictionary of Ancient Athens, New York.

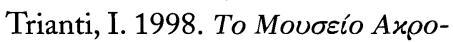
$\pi \delta ́ \lambda \varepsilon \omega \varsigma$, Athens.

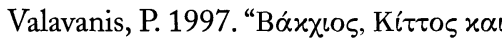

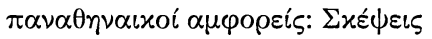
$\gamma \iota \alpha \tau \eta \delta \mu \eta \dot{~} \tau \omega \nu \alpha \tau \tau \iota x \omega \dot{\nu} \varepsilon \rho \gamma \alpha \sigma \tau \eta-$

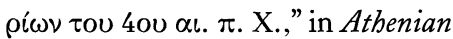
Potters and Painters (Oxbow Monograph 67), ed. J. H. Oakley, W. D. E. Coulson, and O. Palagia, Oxford, pp. 85-95.

Vanderpool, E. 1969. "Three Prize Vases," ArchDelt 24, A', pp. 1-5. - 1970. "Some Attic Inscriptions," Hesperia 39, pp. 40-46. 
1984. "Regulations for the Herakleian Games at Marathon," in Rigsby 1984, pp. 295-296.

Van Straten, F. T. 1981. "Gifts for the Gods" and "Appendix: Votive Offerings Representing Parts of the Human Body (the Greek World)," in Faith, Hope, and Worship: Aspects of Religious Mentality in the Ancient World (Studies in Greek and Roman Religion 2), ed. H. S. Versnel, Leiden, pp. 65-151.

1995. Hiera Kala: Images of Animal Sacrifice in Archaic and Classical Greece, Leiden.

Vickers, M., and D. Gill. 1994. Artful Crafts: Ancient Greek Silverware and Pottery, Oxford.

\section{Catherine M. Keesling}

Georgetown University

DEPARTMENT OF CLASSICS

3 I 9 HEALY

WASHINGTON, D.C. 20057

keeslinc@georgetown.edu
Viviers, D. 1992. Recherches sur les ateliers de sculpteurs et la cité d'Athènes à l'époque archaïque: Endoios, Philergos, Aristoklès (Mémoires de la Classe des Beaux-Arts, $3^{\mathrm{e}}$ ser., 1), Brussels.

Wagner, C. 2000. “The Potters and Athena: Dedications on the Athenian Acropolis," in Periplous: Papers on Classical Art and Archaeology Presented to Sir John Boardman, ed. G. R. Tsetskhladze, A. J. N. W. Prag, and A. M. Snodgrass, London, pp. 383-387.

Walbank, M. B. 1974. "Criteria for the Dating of Fifth-Century Attic Inscriptions," in Phoros: Tribute to Benjamin Dean Meritt, ed. D. W.
Bradeen and M. F. McGregor, Locust Valley, N.Y., pp. 161-169.

Whitley, J. 1997. "Beazley as Theorist," Antiquity 71, pp. 40-47.

Wilhelm, A. 1909. Beiträge zur griechischen Inschriftenkunde (Sonderschriften des Österreichischen archäologischen Instituts in Wien 7), Vienna. 1921. Neue Beiträge zur griechischen Inschriftenkunde 6 (SBWien 183.3), Vienna.

Woodhead, A. G. 1981. The Study of Greek Inscriptions, 2nd ed., Cambridge.

Zagdoun, M.-A. 1989. La sculpture archaïsante dans l'art hellénistique et dans l'art romain du Haut-Empire (BÉFAR 269), Athens. 